\title{
CAMELS-GB: hydrometeorological time series and landscape attributes for 671 catchments in Great Britain
}

\author{
Gemma Coxon $^{1,2}$, Nans Addor ${ }^{3,4}$, John P. Bloomfield ${ }^{5}$, Jim Freer ${ }^{1,2,9}$, Matt Fry ${ }^{6}$, Jamie Hannaford ${ }^{6,7}$, \\ Nicholas J. K. Howden ${ }^{2,8}$, Rosanna Lane ${ }^{1}$, Melinda Lewis ${ }^{5}$, Emma L. Robinson ${ }^{6}$, Thorsten Wagener ${ }^{2,8}$, \\ and Ross Woods ${ }^{2,8}$ \\ ${ }^{1}$ Geographical Sciences, University of Bristol, Bristol, UK \\ ${ }^{2}$ Cabot Institute, University of Bristol, Bristol, UK \\ ${ }^{3}$ Climatic Research Unit, School of Environmental Sciences, University of East Anglia, Norwich, UK \\ ${ }^{4}$ Geography, College of Life and Environmental Sciences, University of Exeter, Exeter, UK \\ ${ }^{5}$ British Geological Survey, Wallingford, Oxfordshire, UK \\ ${ }^{6}$ UK Centre for Ecology \& Hydrology, Maclean Building, Crowmarsh Gifford, Wallingford, UK \\ ${ }^{7}$ Irish Climate and Research Unit, Maynooth University, Maynooth, Ireland \\ ${ }^{8}$ Department of Civil Engineering, University of Bristol, Bristol, UK \\ ${ }^{9}$ Centre for Hydrology, University of Saskatchewan, Canmore, Alberta, Canada
}

Correspondence: Gemma Coxon (gemma.coxon@bristol.ac.uk)

Received: 28 February 2020 - Discussion started: 14 April 2020

Revised: 15 July 2020 - Accepted: 11 August 2020 - Published: 12 October 2020

\begin{abstract}
We present the first large-sample catchment hydrology dataset for Great Britain, CAMELS-GB (Catchment Attributes and MEteorology for Large-sample Studies). CAMELS-GB collates river flows, catchment attributes and catchment boundaries from the UK National River Flow Archive together with a suite of new meteorological time series and catchment attributes. These data are provided for 671 catchments that cover a wide range of climatic, hydrological, landscape, and human management characteristics across Great Britain. Daily time series covering 1970-2015 (a period including several hydrological extreme events) are provided for a range of hydro-meteorological variables including rainfall, potential evapotranspiration, temperature, radiation, humidity, and river flow. A comprehensive set of catchment attributes is quantified including topography, climate, hydrology, land cover, soils, and hydrogeology. Importantly, we also derive human management attributes (including attributes summarising abstractions, returns, and reservoir capacity in each catchment), as well as attributes describing the quality of the flow data including the first set of discharge uncertainty estimates (provided at multiple flow quantiles) for Great Britain. CAMELS-GB (Coxon et al., 2020; available at https://doi.org/10.5285/8344e4f3-d2ea-44f5-8afa-86d2987543a9) is intended for the community as a publicly available, easily accessible dataset to use in a wide range of environmental and modelling analyses.
\end{abstract}

\section{Introduction}

Data underpin our knowledge of the hydrological system. They advance our understanding of water dynamics over a wide range of spatial and temporal scales and are the foundation for water resource planning and regulation. With the emergence of new digital technologies and increased monitoring of the earth system via satellites and sensors, we now have greater access to data than ever before. This prolifera- tion of data has been reflected in recent projects where there has been a focus on sharing data and collaborative research (SWITCH-ON; Ceola et al., 2015), collecting new datasets through the creation of terrestrial environmental observatories (TERENO; Zacharias et al., 2011) or the Critical Zone Observatories (CZOs; Brantley et al., 2017), and cloud-based resources for modelling and visualising large datasets such as 
the Environmental Virtual Observatory (EVO; Emmett et al., 2014) and the CUAHSI HydroDesktop (Ames et al., 2012).

To synthesise hydrologically relevant data and learn from differences between catchments, several large-sample hydrological datasets have been produced over the last decades. These datasets rely on complementary data sources to provide the community with hydrometeorological time series and landscape attributes enabling the characterisation of dozens to thousands of catchments (see Addor et al., 2019, for a review). Many studies have demonstrated the importance of large-sample catchment datasets for understanding regional variability in model performance (Coxon et al., 2019; Kollat et al., 2012; Lane et al., 2019; Newman et al., 2015; Perrin et al., 2003), testing model behaviour and robustness under changing climate conditions (Coron et al., 2012; Fowler et al., 2016; Werkhoven et al., 2008), understanding variability in catchment behaviour including hydrologic signatures and classification (Sawicz et al., 2011; Yadav et al., 2007), assessing trends in hydro-climatic extremes (Berghuijs et al., 2017; Blöschl et al., 2017; Gudmundsson et al., 2019; Hannaford and Buys, 2012; Stahl et al., 2010), exploring model and data uncertainty (Coxon et al., 2014; Westerberg et al., 2016) and regionalising model structures and parameters (Lee et al., 2005; Merz and Blöschl, 2004; Mizukami et al., 2017; Parajka et al., 2005; Pool et al., 2019; Singh et al., 2014).

However, while the number of studies involving data from large samples of catchments is rapidly increasing, publicly available large-sample catchment datasets are still rare. Researchers spend considerable time and effort compiling large-sample catchment datasets, yet these datasets are rarely made available to the community due to data licensing restrictions, strict access policies, or the time required to make these datasets readily usable (Addor et al., 2019; Hannah et al., 2011; Hutton et al., 2016; Nelson, 2009; Viglione et al., 2010). Notable exceptions of open-source, large-sample catchment datasets include the MOPEX dataset that includes hydro-meteorological time series and catchment attributes for 438 US catchments (Duan et al., 2006), the CAMELS dataset that covers 671 US catchments (Catchment Attributes and MEteorology for Large-Sample studies; Addor et al., 2017; Newman et al., 2015), the CAMELS-CL dataset that contains data for 516 catchments across Chile (AlvarezGarreton et al., 2018), and the Canadian model parameter experiment (CANOPEX) database (Arsenault et al., 2016). Daily streamflow records often are not allowed to be redistributed; thus researchers have computed streamflow indices (hydrological signatures) and made them publicly available together with catchment attributes. This is the approach taken for the Global Streamflow Indices and Metadata Archive (Do et al., 2018; Gudmundsson et al., 2018), which includes $>35000$ catchments globally, and the dataset produced by Kuentz et al. (2017) which includes data for $>30000$ catchments across Europe. Overall, datasets for large samples of catchments are vital to advance knowledge on hydrologi- cal processes (Falkenmark and Chapman, 1989; Gupta et al., 2014; McDonnell et al., 2007; Wagener et al., 2010), to underpin common frameworks for model evaluation across complex domains (Ceola et al., 2015) and ensure hydrological research is reusable and reproducible through the use of common datasets and code (Buytaert et al., 2008; Hutton et al., 2016).

In Great Britain, there is a wide availability of gridded, open-source datasets and free access to quality-controlled river flow data via the UK National River Flow Archive (NRFA). While this is a large resource of open data by international standards, these datasets have not yet been combined and processed over a consistent set of catchments and made publicly available in a single location. Further these are dynamic datasets subject to change which cannot support consistent repeatable analysis. Finally, the range of variables and catchment attributes is more limited than other large-sample datasets such as CAMELS.

To address this data gap, we produced the CAMELS-GB dataset (Coxon et al., 2020). CAMELS-GB collates river flows, catchment attributes, and catchment boundaries from the NRFA together with a suite of new meteorological time series and catchment attributes for 671 catchments across Great Britain. In the following sections we describe the key objectives behind CAMELS-GB and how they have shaped the content of the dataset. We also provide a comprehensive description of all data contained within CAMELS-GB including (1) its source data, (2) how the time series and attributes were produced, and (3) a discussion of the associated limitations.

\section{Objectives}

CAMELS (Catchment Attributes and MEteorology for Large-sample Studies) began as an initiative to provide hydro-meteorological time series (Newman et al., 2015) and catchment attributes covering climatic indices, hydrologic signatures, land cover, soil, and geology (Addor et al., 2017) for the contiguous United States. Since then, the dataset has been used widely in other studies (e.g. Addor et al., 2018; Gnann et al., 2019; Pool et al., 2019; Tyralis et al., 2019) and has provided the framework for the production of similar datasets. CAMELS for Chile (CAMELS-CL; AlvarezGarreton et al., 2018) was released, and CAMELS datasets for other countries are in production (Brazil and Australia). While each CAMELS dataset has unique features (for example CAMELS-CL provides snow water equivalent estimates and CAMELS-GB characterises uncertainties in streamflow time series), all the CAMELS datasets consistently apply the same core objective: make hydrometeorological time series and landscape attributes for a large sample of catchments publicly available. They strive to use the same open-source code, variable names, and datasets in order to increase the comparability and reproducibility of hydrological studies. In 
creating the CAMELS-GB dataset, we wanted to build on the successful CAMELS blueprint to provide a large-sample catchment dataset for Great Britain based on four core objectives.

Firstly, we wanted to build on the wealth of data already available for GB catchments but synthesise the diverse range of data into a single, consistent, up-to-date dataset. The UK has a rich history of leading research in catchment hydrology and integrating large samples of data for many catchments. For example, the Flood Studies Report (NERC, 1975) extracted high rainfall events, peak flows, and catchment characteristics for 138 catchments to support flood estimation using catchment characteristics. The UK NRFA contains a wealth of data (including flow time series, catchment attributes, catchment masks) for the UK gauging station network which contains approximately 1500 gauging stations as summarised in the UK Hydrometric Register (Marsh and Hannaford, 2008). Where possible, we have made use of the existing data available on the NRFA in CAMELS-GB to ensure consistency and to avoid duplicating efforts. We also build on these existing datasets by providing new catchment attributes and time series that are currently not available on the NRFA (e.g. potential evapotranspiration, temperature, soils, and human impacts).

Secondly, we wanted to provide a large-sample catchment dataset for Great Britain based on information that (i) is sufficiently detailed to enable the exploration of hydrological processes at the catchment scale, (ii) is well documented (ideally in open-access peer-reviewed journals), (iii) relies on stateof-the-art methods, and (iv) includes recent observations. Consequently, some catchment attributes currently available on the NRFA have been re-calculated for CAMELS-GB as better-quality or higher-spatial-resolution datasets are now available (e.g. to derive land cover and hydrogeological attributes). This also means that we have primarily used the best available national datasets for the derivation of the catchment time series and attributes. These time series and attributes can be compared at a later stage to estimates derived from global datasets.

Thirdly, we wanted to provide qualitative and quantitative estimates of the limitations/uncertainties of the data provided in CAMELS-GB. Characterising data uncertainties is crucial as different data collection techniques or quality standards can bias comparisons between catchments. By providing quantitative estimates of uncertainty (including the first set of national discharge uncertainty estimates), we hope to raise awareness and encourage users of the dataset to consider these uncertainties in their analyses.

Finally, where possible, we have ensured that the underlying datasets (such as gridded geophysical and meteorological data) are publicly available to allow reproducibility and reusability.

\section{Catchments}

The catchments included in the CAMELS-GB dataset were selected from the UK NRFA Service Level Agreement (SLA) network. Approximately half of the NRFA gauging stations are designated as SLA stations in collaboration with measuring authorities (as described in Dixon et al., 2013; Hannaford, 2004), embracing catchments which are considered to contribute most to the overall strategic utility of the gauging network. Selection criteria include hydrometric performance, representativeness of the catchment, length of record, and degree of artificial disturbance to the natural flow regime. The flow records for these SLA stations are subject to an additional level of validation on the NRFA and are also used to calculate performance metrics that quantify completeness and quality (see the methods and metrics outlined in Dixon et al., 2013, and Muchan and Dixon, 2014). This process focuses on the credibility of flows in the extreme ranges and the need to maintain sensibly complete time series, thus providing good-quality and long time series for CAMELS-GB. All gauges from the UK SLA network are included in CAMELSGB except catchments from Northern Ireland (due to a lack of consistent meteorological datasets across the UK) and two gauges where no suitable surface area catchment could be derived (e.g. a groundwater spring for which surface catchment area is not hydrologically relevant). This results in a total of 671 catchments (includes nested catchments - see Fig. S1 in the Supplement) covering a wide range of climatic and hydrologic diversity across GB that is representative of the wider gauging network (see Figs. S2 and S3 for a comparison of key attributes for the CAMELS-GB catchments and all GB gauged catchments).

In keeping with the CAMELS-CL dataset (AlvarezGarreton et al., 2018), we chose to include both nonimpacted and human-impacted catchments in the dataset complemented with catchment attributes on the size and type of human impacts these catchments experience. Humanimpacted catchments are provided to support the current IAHS Panta Rhei decade which is focused on how the water cycle is impacted by human activities (McMillan et al., 2016; Montanari et al., 2013) and also enable national-scale hydrological modelling and analyses across catchments that are impacted by reservoirs, abstractions, and land use change.

\section{Catchment masks}

Catchment masks are provided in the dataset to allow other users to create their own catchment hydro-meteorological time series and attributes from gridded datasets not used in this study. The catchment masks were derived from the UK Centre for Ecology \& Hydrology (CEH) $50 \mathrm{~m}$ Integrated Hydrological Digital Terrain Model (IHDTM; Morris and Flavin, 1990) and a set of $50 \mathrm{~m}$ flow direction grids. The flow direction grids are based on a digital elevation model and contours from the UK Ordnance Survey Land- 
Form Panorama dataset (now withdrawn and superseded by OS Terrain 50) and hydrologically corrected by "burning in" rivers using CEH's $1: 50 \mathrm{~K}$ digital river network (Moore et al., 2000). The catchment boundaries were created using bespoke code for identifying all IHDTM cells upstream of the most appropriate grid cell to represent the gauging station location and generate a meaningful "real-world" boundary around these cells. In a few cases, where the topographical data make automated definition difficult, catchment masks were manually derived. Catchment masks are provided as shapefiles in the OSGB 1936 co-ordinate system (British National Grid).

ASCII files were generated from the shapefiles by converting the shapefile onto a $50 \mathrm{~m}$ raster grid and then exporting the rasters to individual ASCII files. These files are used to calculate all catchment-averaged time series and attributes in CAMELS-GB. To calculate the catchment-average time series/attribute for each dataset, the $50 \mathrm{~m}$ grid cells in each catchment mask were assigned a value from the respective dataset grid cell (determined by which dataset grid cell the lower left-hand corner of the mask grid cell lay within), and an arithmetic mean of these values was calculated (unless specified otherwise). This ensures a weighted average is calculated that accounts for the differences in grid cell sizes between the catchment mask (on a $50 \mathrm{~m}$ grid) and any other datasets (often on a $1 \mathrm{~km}$ grid). This is particularly important for smaller catchments in areas of highly variable data.

It is important for users to note that as the topographical boundaries are used throughout the study to quantify the hydrometeorological time series and attributes, this could mean significant errors where the catchment area is poorly defined.

\section{Time series data}

Daily meteorological and hydrological time series data are provided for the 671 CAMELS-GB catchments including flow, rainfall, potential evapotranspiration, temperature, short-wave radiation, long-wave radiation, specific humidity, and wind speed (summarised in Table 1). These datasets were chosen for inclusion in CAMELS-GB to cover the common forcing and evaluation data needed for catchment hydrological modelling, to allow users to derive different estimates of potential evapotranspiration, and to provide the key hydrometeorological data for catchment characterisation.

Hydro-meteorological time series data for the 671 catchments were obtained from a number of datasets for a 45 year time period from 1 October 1970 to 30 September 2015. These long time series enable the dataset's use in trend analysis, provide a valuable dataset for model forcing and evaluation, and ensure the robust calculation of hydro-climatic signatures. These long time series also cover a wide range of nationally important hydroclimatic events such as the 1976 drought and 2007 floods (see summaries of UK drought and flood episodes for a more extensive review including Fol- land et al., 2015; Marsh et al., 2007; Stevens et al., 2016). From previous analyses, it is important to note that there are key known non-stationarities over this period in hydrometeorological data and human activity (see for example Hannaford and Marsh, 2006) for GB. For example, seasonal changes in precipitation have been well documented (Jenkins et al., 2009) and linked to changes in river flow (Hannaford and Buys, 2012; Harrigan et al., 2018).

\subsection{Meteorological time series}

Meteorological time series were derived from high-quality national gridded products chosen for their high spatial resolution $\left(1 \mathrm{~km}^{2}\right)$, long time series availability, and basis on UK observational networks. For each of the meteorological datasets, daily time series of catchment areal averages were calculated using the catchment masks and methods described in Sect. 4. These time series are available for all CAMELSGB catchments with no missing data.

Daily rainfall time series were derived from the $\mathrm{CEH}$ Gridded Estimates of Areal Rainfall dataset (CEH-GEAR) (Keller et al., 2015; Tanguy et al., 2016). This dataset consists of $1 \mathrm{~km}^{2}$ gridded estimates of daily rainfall for Great Britain and Northern Ireland from 1 January 1961 to 31 December 2015. The daily rainfall grids are derived using natural neighbour interpolation of a national database of qualitycontrolled, observed precipitations from the Met Office UK rain gauge network. It should be noted that the rainfall time series available in CAMELS-GB use the same underlying data but are not identical to catchment-average rainfall series available from the NRFA which are derived using only $1 \mathrm{~km}$ grid cells with $>50 \%$ of their area within the catchment boundary.

Daily meteorological time series were derived from the Climate Hydrology and Ecology research Support System meteorology dataset (CHESS-met; Robinson et al., 2017a). The CHESS-met dataset consists of daily $1 \mathrm{~km}^{2}$ gridded estimates for Great Britain from 1 January 1961 to 31 December 2015 and includes several meteorological variables derived from observational data (see Table 1). CHESS-met was derived from the observation-based MORECS, which is a $40 \mathrm{~km}$ resolution gridded dataset, derived by interpolating daily station data (Hough and Jones, 1997; Thompson et al., 1981). The CHESS-met variables are obtained by downscaling MORECS variables to $1 \mathrm{~km}$ resolution and adjusting for local topography using lapse rates, modelled wind speeds, and empirical relationships. CHESS-met air temperature and wind speed were directly downscaled from MORECS, specific humidity was calculated from MORECS vapour pressure, downward short-wave radiation was calculated from MORECS sunshine hours, and long-wave radiation was calculated from the downscaled temperature, vapour pressure, and sunshine hours (see Robinson et al., 2017b, for detail).

Daily potential evapotranspiration time series were derived from the Climate Hydrology and Ecology re- 
Table 1. Summary table of catchment hydro-meteorological time series available in CAMELS-GB.

\begin{tabular}{|c|c|c|c|c|}
\hline Time series class & Time series name & Description & Unit & Data source \\
\hline \multirow{8}{*}{$\begin{array}{l}\text { Meteorological } \\
\text { time series } \\
\text { (available from } \\
1 \text { Oct } 1970 \\
\text { to } 30 \text { Sep 2015) }\end{array}$} & precipitation & catchment daily averaged precipitation & $\mathrm{mm} \mathrm{d}^{-1}$ & $\begin{array}{l}\text { CEH-GEAR (Keller et } \\
\text { al., 2015; Tanguy et al., } \\
\text { 2016) }\end{array}$ \\
\hline & pet & $\begin{array}{l}\text { catchment daily averaged potential evapotran- } \\
\text { spiration for a well-watered grass } \\
\text { (Penman-Monteith equation) }\end{array}$ & $\mathrm{mm} \mathrm{d}^{-1}$ & \\
\hline & peti & $\begin{array}{l}\text { catchment daily averaged potential evapotran- } \\
\text { spiration for a well-watered grass (Penman- } \\
\text { Monteith equation with a correction added for } \\
\text { interception on days where rainfall has } \\
\text { occurred) }\end{array}$ & $\mathrm{mm} \mathrm{d}^{-1}$ & $\begin{array}{l}\text { CHESS-PE (Robinson } \\
\text { et al., 2017a, b) }\end{array}$ \\
\hline & temperature & catchment daily averaged temperature & ${ }^{\circ} \mathrm{C}$ & $\begin{array}{l}\text { CHESS-met (Robinson } \\
\text { et al., 2017a) }\end{array}$ \\
\hline & windspeed & catchment daily averaged wind speed & $\mathrm{ms}^{-1}$ & \\
\hline & humidity & catchment daily averaged specific humidity & $\mathrm{g} \mathrm{kg}^{-1}$ & \\
\hline & shortwave_rad & $\begin{array}{l}\text { catchment daily averaged downward short- } \\
\text { wave radiation }\end{array}$ & $\mathrm{W} \mathrm{m}^{-2}$ & \\
\hline & longwave_rad & catchment daily averaged long-wave radiation & $\mathrm{W} \mathrm{m}^{-2}$ & \\
\hline \multirow{2}{*}{$\begin{array}{l}\text { Hydrological } \\
\text { time series } \\
\text { (available from } \\
1 \text { Oct } 1970 \\
\text { to } 30 \text { Sep 2015) }\end{array}$} & discharge_spec & $\begin{array}{l}\text { catchment-specific discharge (converted to mil- } \\
\text { limetres per day using catchment areas de- } \\
\text { scribed in Sect. 6.1) }\end{array}$ & $\mathrm{mm} \mathrm{d}^{-1}$ & $\begin{array}{l}\text { UK National River } \\
\text { Flow Archive using the } \\
\text { NRFA API* }\end{array}$ \\
\hline & discharge_vol & catchment discharge & $\mathrm{m}^{3} \mathrm{~s}^{-1}$ & \\
\hline
\end{tabular}

* https://nrfaapps.ceh.ac.uk/nrfa/nrfa-api.html (last access: 11 December 2019).

search Support System Potential Evapotranspiration dataset (CHESS-PE; Robinson et al., 2016). The CHESS-PE dataset consists of daily $1 \mathrm{~km}^{2}$ gridded estimates of potential evapotranspiration for Great Britain from 1 January 1961 to 31 December 2015. Potential evapotranspiration is calculated using the Penman-Monteith equation and CHESS-met datasets (see Robinson et al., 2017b). In recognition of the uncertainty in PET estimates, we provide two estimates of potential evapotranspiration available from CHESS-PE. The first estimate (PET) is calculated using the Penman-Monteith equation for FAO-defined well-watered grass (Allen et al., 1998) and is used to calculate all subsequent PET catchment attributes provided in CAMELS-GB. This estimate only accounts for transpiration and does not allow for canopy interception. The second estimate (PETI) uses the same meteorological data and the Penman-Monteith equation for well-watered grass, but a correction is added for interception on days where rainfall has occurred (Robinson et al., 2017b). The seasonal differences between these two data products can be seen in Fig. S12b. Generally, the PETI estimate with the interception correction is higher because interception is a more ef- fective flux than transpiration under the same meteorological conditions. CHESS PETI can be between $5 \%$ and $25 \%$ higher than CHESS PET at the grid-box level, whereas at a regional level, CHESS PETI is $7 \%$ higher than PET in England and $11 \%$ higher than PET in Scotland overall (Robinson et al., 2017b). In comparison to other PET products commonly used in GB, the CHESS PETI estimate is similar to grass-only MORECS (the United Kingdom Meteorological Office rainfall and evaporation calculation system; Hough and Jones, 1997), which has its own interception correction. It is important to note that the effect of seasonal land cover is not accounted for in the CHESS-PE products; this means that for arable agriculture which may have bare soil for part of the year, or deciduous trees which lose leaves and thus reduce both transpiration and interception, the potential evapotranspiration could be lower during winter than is estimated here. This leads to a varying difference between the PET and PETI of grass and other land cover types throughout the year (Beven, 1979). 


\subsection{Hydrological time series}

Daily streamflow data for the 671 gauges were obtained from the UK NRFA on the 27 March 2019 using the NRFA API (https://nrfaapps.ceh.ac.uk/nrfa/nrfa-api.html, last access: 11 December 2019). These data are collected by measuring authorities including the Environment Agency (EA), Natural Resources Wales (NRW), and Scottish Environmental Protection Agency (SEPA) and then quality controlled, on an ongoing annual cycle, before being uploaded to the NRFA site. It is important to note that, on occasion, these flow time series are reprocessed when a rating curve is revised (for example) and so there may be differences between the flow time series on the NRFA website and contained in CAMELS-GB. If users wish to extend the time series beyond that available in CAMELS-GB, we suggest downloading and using the extended flow time series available from the NRFA website and recalculating the hydrological signatures using the code we have archived (see Sect. 6.3). Data are provided in cubic metres per second and millimetre per day and calculated using catchment areas derived from the catchment boundaries described in Sect. 4.

Figure 1a shows the flow data availability for all gauges contained in the CAMELS-GB dataset covering different time periods. Over the 45-year time period (1970-2015), $60 \%$ (401) of the gauges have $5 \%$ missing flow data or less, and $81 \%$ (542) of the gauges have $20 \%$ missing flow data or less. Figure $1 \mathrm{~b}$ shows the number of years of available flow data for each CAMELS-GB gauge across Great Britain. A total of $97 \%$ (654) of the gauges have at least 20 years of data, and $70 \%$ (468) of the gauges have at least 40 years of data. Overall, there is good spatial coverage of long flow time series across Great Britain, with slightly shorter time series concentrated in Scotland and in central GB.

\section{Catchment attributes}

\subsection{Location, area, and topographic data}

Catchment attributes describing the location and topography were extracted for each catchment from the NRFA (see Table 2). Catchment areas are calculated from the catchment masks described in Sect. 4. Catchment elevation is extracted from CEH's $50 \mathrm{~m}$ Integrated Hydrological Digital Terrain Model, and the minimum and maximum catchment elevations within the catchment mask are provided alongside different percentiles (10th, 50th, and 90th). On occasion, minimum elevation may differ slightly from the gauge elevation attributes. The latter are as reported to the NRFA by the measuring authorities and derived in a variety of ways with different levels of accuracy. Furthermore some may refer to the bank top, the gauge minimum, or a local datum. The minimum elevation attribute provides a more consistent metric (though itself limited in accuracy due to the $50 \mathrm{~m}$ grid representation). Mean elevation and mean drainage path slope are also provided from pre-computed grids developed for the Flood Estimation Handbook (Bayliss, 1999). The mean drainage path slope provides an index of overall catchment steepness by calculating the mean of all inter-nodal slopes from the IHDTM for the catchment. For two catchments (18011 and 26006) where automatic derivation of the catchment boundary from the IHDTM for the gauge location was not possible and catchment masks were manually derived, no appropriate pre-computed values for the mean elevation or mean drainage path slope were available.

\subsection{Climatic indices}

Climatic indices were derived using the catchment daily rainfall, potential evapotranspiration, and temperature time series described in Sect. 5.1 (see Table 2). The Penman-Monteith formulation without correction for interception is used to calculate all PET catchment attributes provided in CAMELSGB as it has more consistency with other global and national PET products. To provide consistency with previous CAMELS datasets, we compute the same climatic indices for all catchments in CAMELS-GB. However, it is important to note that in CAMELS-GB climatic indices are calculated for the full meteorological time series available in CAMELS-GB (water years from 1 October 1970 to 30 September 2015), whereas CAMELS and CAMELS-CL both use the water years from 1990 to 2009. The meteorological time series and code (https://github.com/naddor/camels, last access: 11 December 2019) are provided for users to calculate indices over different time periods if required.

\subsection{Hydrologic signatures}

Hydrologic signatures were derived using the catchment daily discharge and rainfall time series described in Sect. 5.1 and 5.2 (see Table 2). To provide consistency with the previous CAMELS datasets, we compute the same hydrologic signatures for all catchments in CAMELS-GB but add an additional formulation of base flow index developed by the UK Centre for Ecology \& Hydrology and commonly used in Great Britain (Gustard et al., 1992; see Appendix A and Fig. S12a). Hydrologic signatures are calculated for the flow time series available during water years from 1 October 1970 to 30 September 2015 (previous CAMELS datasets calculated these metrics during water years from 1990 to 2009) using code available on GitHub (https://github.com/naddor/ camels, last access: 11 December 2019). We advise users to take the length of the flow time series and percentage of missing data (available in the hydrometry catchment attributes see Sect. 6.7) into account when comparing hydrologic signatures across catchments. 
Table 2. Summary table of catchment attributes available in CAMELS-GB.

\begin{tabular}{|c|c|c|c|c|}
\hline Attribute class & Attribute name & Description & Unit & Data source \\
\hline \multirow[t]{2}{*}{$\begin{array}{l}\text { Location and } \\
\text { topography }\end{array}$} & $\begin{array}{l}\text { gauge_name } \\
\text { gauge_lat } \\
\text { gauge_lon } \\
\text { gauge_easting } \\
\text { gauge_northing } \\
\text { gauge_elev }\end{array}$ & $\begin{array}{l}\text { catchment identifier (corresponds to the gauging } \\
\text { station ID provided by the NRFA) } \\
\text { gauge name (river name followed by gauging sta- } \\
\text { tion name) } \\
\text { gauge latitude } \\
\text { gauge longitude } \\
\text { gauge easting } \\
\text { gauge northing } \\
\text { gauge elevation }\end{array}$ & $\begin{array}{l}- \\
\circ \\
\circ \\
\mathrm{m} \\
\mathrm{m} \\
\mathrm{m} \text { a.s.l. }\end{array}$ & $\begin{array}{lr}\text { UK } & \text { National } \\
\text { River } & \text { Flow } \\
\text { Archive } & \text { using } \\
\text { the NRFA } & \text { API }\end{array}$ \\
\hline & $\begin{array}{l}\text { area } \\
\text { dpsbar } \\
\text { elev_mean } \\
\text { elev_min } \\
\text { elev_10 } \\
\text { elev_50 } \\
\text { elev_90 } \\
\text { elev_max }\end{array}$ & $\begin{array}{l}\text { catchment area } \\
\text { catchment mean drainage path slope } \\
\text { catchment mean elevation } \\
\text { catchment minimum elevation } \\
\text { catchment 10th percentile elevation } \\
\text { catchment median elevation } \\
\text { catchment 90th percentile elevation } \\
\text { catchment maximum elevation }\end{array}$ & $\begin{array}{l}\mathrm{km}^{2} \\
\mathrm{~m} \mathrm{~km}^{-1} \\
\mathrm{~m} \text { a.s.l. } \\
\mathrm{m} \text { a.s.l. } \\
\mathrm{m} \text { a.s.l. } \\
\text { m a.s.l. } \\
\text { m a.s.l. } \\
\text { m a.s.l. }\end{array}$ & $\begin{array}{l}\text { CEH's Inte- } \\
\text { grated Hydro- } \\
\text { logical Digital } \\
\text { Terrain Model } \\
\text { (Morris and } \\
\text { Flavin, 1990) }\end{array}$ \\
\hline \multirow{11}{*}{$\begin{array}{l}\text { Climatic } \\
\text { indices (com- } \\
\text { puted for } \\
1 \text { Oct 1970 to } \\
30 \text { Sep 2015) }\end{array}$} & p_mean & mean daily precipitation & $\mathrm{mm} \mathrm{d}^{-1}$ & \multirow{11}{*}{$\begin{array}{l}\text { Catchment } \\
\text { time series of } \\
\text { precipitation, } \\
\text { potential evap- } \\
\text { otranspiration, } \\
\text { and tempera- } \\
\text { ture described } \\
\text { in Sect. } 5.1 \text { and } \\
\text { Table } 1\end{array}$} \\
\hline & pet_mean & $\begin{array}{l}\text { mean daily PET (Penman-Monteith equation with- } \\
\text { out interception correction) }\end{array}$ & $\mathrm{mm} \mathrm{d}^{-1}$ & \\
\hline & aridity & $\begin{array}{l}\text { aridity, calculated as the ratio of mean daily poten- } \\
\text { tial evapotranspiration to mean daily precipitation }\end{array}$ & - & \\
\hline & p_seasonality & $\begin{array}{l}\text { seasonality and timing of precipitation (estimated } \\
\text { using sine curves to represent the annual temper- } \\
\text { ature and precipitation cycles, positive (negative) } \\
\text { values indicate that precipitation peaks in summer } \\
\text { (winter), and values close to zero indicate uniform } \\
\text { precipitation throughout the year). See Eq. (14) in } \\
\text { Woods (2009) }\end{array}$ & - & \\
\hline & frac_snow & $\begin{array}{l}\text { fraction of precipitation falling as snow (for days } \\
\text { colder than } 0^{\circ} \mathrm{C} \text { ) }\end{array}$ & - & \\
\hline & high_prec_freq & $\begin{array}{l}\text { frequency of high-precipitation days ( } \geq 5 \text { times } \\
\text { mean daily precipitation) }\end{array}$ & $\mathrm{d} \mathrm{yr}^{-1}$ & \\
\hline & high_prec_dur & $\begin{array}{l}\text { average duration of high-precipitation events (num- } \\
\text { ber of consecutive days } \geq 5 \text { times mean daily pre- } \\
\text { cipitation) }\end{array}$ & $\mathrm{d}$ & \\
\hline & high_prec_timing & $\begin{array}{l}\text { season during which most high-precipitation days } \\
(\geq 5 \text { times mean daily precipitation) occur. If two } \\
\text { seasons register the same number of events, a value } \\
\text { of } \mathrm{NaN} \text { is given. }\end{array}$ & season & \\
\hline & low_prec_freq & frequency of dry days $\left(<1 \mathrm{~mm} \mathrm{~d}^{-1}\right)$ & $\mathrm{d} \mathrm{yr}^{-1}$ & \\
\hline & low_prec_dur & $\begin{array}{l}\text { average duration of dry periods (number of consec- } \\
\text { utive days }<1 \mathrm{~mm} \mathrm{~d}^{-1} \text { ) }\end{array}$ & d & \\
\hline & low_prec_timing & $\begin{array}{l}\text { season during which most dry days }\left(<1 \mathrm{~mm} \mathrm{~d}^{-1}\right) \\
\text { occur. If two seasons register the same number of } \\
\text { events, a value of } \mathrm{NaN} \text { is given. }\end{array}$ & season & \\
\hline
\end{tabular}


Table 2. Continued.

\begin{tabular}{|c|c|c|c|c|}
\hline Attribute class & Attribute name & Description & Unit & Data source \\
\hline \multirow{14}{*}{$\begin{array}{l}\text { Hydrologic } \\
\text { signatures } \\
\text { (computed for } \\
1 \text { Oct } 1970 \text { to } \\
30 \text { Sep 2015) }\end{array}$} & q_mean & mean daily discharge & $\mathrm{mm} \mathrm{d}^{-1}$ & \multirow{14}{*}{$\begin{array}{l}\text { Catchment } \\
\text { time series of } \\
\text { streamflow and } \\
\text { precipitation } \\
\text { described in } \\
\text { Sect. } 5.2 \text { and } \\
5.1 \text { respectively } \\
\text { and Table } 1 . \\
\text { Thresholds for } \\
\text { high/low flow } \\
\text { frequency and } \\
\text { duration were } \\
\text { obtained from } \\
\text { Clausen and } \\
\text { Biggs (2000) } \\
\text { and Westerberg } \\
\text { and McMillan } \\
\text { (2015) }\end{array}$} \\
\hline & runoff_ratio & $\begin{array}{l}\text { runoff ratio, calculated as the ratio of mean daily } \\
\text { discharge to mean daily precipitation }\end{array}$ & - & \\
\hline & stream_elas & $\begin{array}{l}\text { streamflow precipitation elasticity (sensitivity of } \\
\text { streamflow to changes in precipitation at the an- } \\
\text { nual timescale, using the mean daily discharge as } \\
\text { reference). See Eq. (7) in Sankarasubramanian et } \\
\text { al. }(2001) \text {, with the last element being } \bar{P} / \bar{Q} \text { not } \\
\bar{Q} / \bar{P}\end{array}$ & - & \\
\hline & slope_fdc & $\begin{array}{l}\text { slope of the flow duration curve (between the log- } \\
\text { transformed 33rd and 66th streamflow percentiles) } \\
\text { (Yadav et al., 2007). There can be NAs in this metric } \\
\text { when over a third of the flow time series are zeros } \\
\text { (see zero_q_freq) }\end{array}$ & - & \\
\hline & baseflow_index & $\begin{array}{l}\text { base flow index (ratio of mean daily base flow to } \\
\text { daily discharge, hydrograph separation performed } \\
\text { using the Ladson et al., 2013, digital filter) }\end{array}$ & - & \\
\hline & baseflow_index_ceh & $\begin{array}{l}\text { base flow index (ratio of mean daily base flow to } \\
\text { daily discharge, hydrograph separation performed } \\
\text { using the Gustard et al. (1992) method described in } \\
\text { Appendix A) }\end{array}$ & - & \\
\hline & hfd_mean & $\begin{array}{l}\text { mean half-flow date (date on which the cumulative } \\
\text { discharge since } 1 \text { Oct reaches half of the annual dis- } \\
\text { charge) }\end{array}$ & days since 1 Oct & \\
\hline & Q5 & $5 \%$ flow quantile (low flow) & $\mathrm{mm} \mathrm{d}^{-1}$ & \\
\hline & Q95 & $95 \%$ flow quantile (high flow) & $\mathrm{mm} \mathrm{d}^{-1}$ & \\
\hline & high_q_freq & $\begin{array}{l}\text { frequency of high-flow days ( }>9 \text { times the median } \\
\text { daily flow) }\end{array}$ & $\mathrm{dyr}^{-1}$ & \\
\hline & high_q_dur & $\begin{array}{l}\text { average duration of high-flow events (number of } \\
\text { consecutive days }>9 \text { times the median daily flow) }\end{array}$ & $\mathrm{d}$ & \\
\hline & low_q_freq & $\begin{array}{l}\text { frequency of low-flow days }(<0.2 \text { times the mean } \\
\text { daily flow) }\end{array}$ & $\mathrm{dyr}^{-1}$ & \\
\hline & low_q_dur & $\begin{array}{l}\text { average duration of low-flow events (number of } \\
\text { consecutive days }<0.2 \text { times the mean daily flow) }\end{array}$ & $\mathrm{d}$ & \\
\hline & zero_q_freq & fraction of days with $Q=0$ & - & \\
\hline \multirow{9}{*}{$\begin{array}{l}\text { Land cover } \\
\text { attributes }\end{array}$} & dwood_perc & percentage cover of deciduous woodland & $\%$ & \multirow{9}{*}{$\begin{array}{l}1 \mathrm{~km} \text { percent- } \\
\text { age target class, } \\
\text { Land Cover } \\
\text { Map } 2015 \\
\text { (Rowland et al., } \\
2017)\end{array}$} \\
\hline & ewood_perc & percentage cover of evergreen woodland & $\%$ & \\
\hline & grass_perc & percentage cover of grass and pasture & $\%$ & \\
\hline & shrub_perc & $\begin{array}{l}\text { percentage cover of medium-scale vegetation } \\
\text { (shrubs) }\end{array}$ & $\%$ & \\
\hline & crop_perc & percentage cover of crops & $\%$ & \\
\hline & urban_perc & percentage cover of suburban and urban & $\%$ & \\
\hline & inwater_perc & percentage cover of inland water & $\%$ & \\
\hline & bares_perc & percentage cover of bare soil and rocks & $\%$ & \\
\hline & dom_land_cover & $\begin{array}{l}\text { dominant land cover (the land cover class that has } \\
\text { the highest percentage cover in each catchment) }\end{array}$ & - & \\
\hline
\end{tabular}


Table 2. Continued.

\begin{tabular}{|c|c|c|c|c|}
\hline Attribute class & Attribute name & Description & Unit & Data source \\
\hline \multirow{12}{*}{$\begin{array}{l}\text { Soil attributes } \\
\text { Each soil at- } \\
\text { tribute (apart } \\
\text { from percent- } \\
\text { age sand, silt, } \\
\text { clay, and or- } \\
\text { ganic content) } \\
\text { is accompanied } \\
\text { by the 5th, } \\
50 \text { th, and 95th } \\
\text { percentiles of } \\
\text { that attribute } \\
\text { across the } \\
\text { catchment and } \\
\text { the percentage } \\
\text { missing }\end{array}$} & sand_perc & percentage sand & $\%$ & \multirow{12}{*}{$\begin{array}{l}\text { European Soil } \\
\text { Database } \\
\text { Derived } \\
\text { Data prod- } \\
\text { uct (Hiederer, } \\
2013 \mathrm{a} \text {, b), and } \\
\text { the modelled } \\
\text { depth-to- } \\
\text { bedrock global } \\
\text { product (Pel- } \\
\text { letier et al., } \\
\text { 2016b) }\end{array}$} \\
\hline & silt_perc & percentage silt & $\%$ & \\
\hline & clay_perc & percentage clay & $\%$ & \\
\hline & organic_perc & percentage organic content & $\%$ & \\
\hline & bulkdens & bulk density & $\mathrm{g} \mathrm{cm}^{-3}$ & \\
\hline & tawc & $\begin{array}{l}\text { total available water content (calculated over the } \\
\text { soil depth available for roots) }\end{array}$ & $\mathrm{mm}$ & \\
\hline & porosity_cosby & $\begin{array}{l}\text { volumetric porosity (saturated water content esti- } \\
\text { mated using a pedo-transfer function based on sand } \\
\text { and clay fractions) }\end{array}$ & - & \\
\hline & porosity_hypres & $\begin{array}{l}\text { volumetric porosity (saturated water content esti- } \\
\text { mated using a pedo-transfer function based on silt, } \\
\text { clay and organic fractions, bulk density, and topsoil) }\end{array}$ & - & \\
\hline & conductivity_cosby & $\begin{array}{l}\text { saturated hydraulic conductivity (estimated using a } \\
\text { pedo-transfer function based on sand and clay frac- } \\
\text { tions) }\end{array}$ & $\mathrm{cm} \mathrm{h}^{-1}$ & \\
\hline & conductivity_hypres & $\begin{array}{l}\text { saturated hydraulic conductivity (estimated using a } \\
\text { pedo-transfer function based on silt, clay and or- } \\
\text { ganic fractions, bulk density, and topsoil) }\end{array}$ & $\mathrm{cm} \mathrm{h}^{-1}$ & \\
\hline & root_depth & depth available for roots & $\mathrm{m}$ & \\
\hline & soil_depth_pelletier & depth to bedrock (maximum $50 \mathrm{~m}$ ) & $\mathrm{m}$ & \\
\hline \multirow{9}{*}{$\begin{array}{l}\text { Hydrogeology } \\
\text { attributes }\end{array}$} & inter_high_perc & significant intergranular flow - high productivity & $\%$ & \multirow{9}{*}{$\begin{array}{l}\text { British Geo- } \\
\text { logical Survey } \\
\text { hydrogeology } \\
\text { map (BGS, } \\
2019 \text { ) and } \\
\text { superficial } \\
\text { deposit map }\end{array}$} \\
\hline & inter_mod_perc & $\begin{array}{l}\text { significant intergranular flow - moderate productiv- } \\
\text { ity }\end{array}$ & $\%$ & \\
\hline & inter_low_perc & significant intergranular flow - low productivity & $\%$ & \\
\hline & frac_high_perc & flow through fractures - high productivity & $\%$ & \\
\hline & frac_mod_perc & flow through fractures - moderate productivity & $\%$ & \\
\hline & frac_low_perc & flow through fractures - low productivity & $\%$ & \\
\hline & no_gw_perc & rocks with essentially no groundwater & $\%$ & \\
\hline & low_nsig_perc & $\begin{array}{l}\text { generally low productivity (intergranular flow) but } \\
\text { some not significant aquifer }\end{array}$ & $\%$ & \\
\hline & nsig_low_perc & $\begin{array}{l}\text { generally not significant aquifer but some low pro- } \\
\text { ductivity (intergranular flow) }\end{array}$ & $\%$ & \\
\hline
\end{tabular}


Table 2. Continued.

\begin{tabular}{|c|c|c|c|c|}
\hline Attribute class & Attribute name & Description & Unit & Data source \\
\hline \multirow[t]{9}{*}{ Hydrometry } & station_type & $\begin{array}{l}\text { gauging station type denoted by the following ab- } \\
\text { breviations (B: broad-crested weir; C: crump pro- } \\
\text { file single-crest weir; CB: compound broad-crested } \\
\text { weir; CC: compound crump weir; EM: electromag- } \\
\text { netic gauging station; EW: Essex weir; FL: flume; } \\
\text { FV: flat V triangular profile weir; MIS: miscella- } \\
\text { neous; TP: rectangular thin-plate weir; US: ultra- } \\
\text { sonic gauging station; VA: velocity-area gauging } \\
\text { station; VN: triangular (V notch) thin-plate weir). } \\
\text { Two abbreviations may be applied to each station } \\
\text { relating to the measurement of low or high flows. }\end{array}$ & - & $\begin{array}{lr}\text { UK } & \text { National } \\
\text { River } & \text { Flow } \\
\text { Archive } & \text { using } \\
\text { the NRFA API }\end{array}$ \\
\hline & flow_period_start & $\begin{array}{l}\text { first date that daily flow time series provided in } \\
\text { CAMELS-GB are available for this gauging station }\end{array}$ & - & \multirow{3}{*}{$\begin{array}{l}\text { Catchment } \\
\text { time series of } \\
\text { streamflow } \\
\text { described in } \\
\text { Sect. } 5.2\end{array}$} \\
\hline & flow_period_end & $\begin{array}{l}\text { end date that daily flow time series provided in } \\
\text { CAMELS-GB are available for this gauging station }\end{array}$ & - & \\
\hline & flow_perc_complete & $\begin{array}{l}\text { percentage of days with flow time series available } \\
\text { from } 1 \text { Oct } 1970 \text { to } 31 \text { Sep } 2015\end{array}$ & $\%$ & \\
\hline & bankfull_flow & $\begin{array}{l}\text { flow at which the river begins to overlap the banks } \\
\text { at a gauging } \\
\text { station (obtained from stage-discharge relation- } \\
\text { ships so may be derived by extrapolation) }\end{array}$ & $\mathrm{m}^{3} \mathrm{~s}^{-1}$ & \multirow[t]{2}{*}{$\begin{array}{l}\text { UK National } \\
\text { River Flow } \\
\text { Archive using } \\
\text { the NRFA API }\end{array}$} \\
\hline & structurefull_flow & $\begin{array}{l}\text { flow at which the river begins to the wingwalls of a } \\
\text { structure at a gauging } \\
\text { station (obtained from stage-discharge relation- } \\
\text { ships so may be derived by extrapolation) }\end{array}$ & $\mathrm{m}^{3} \mathrm{~s}^{-1}$ & \\
\hline & qXX_uncert_upper & $\begin{array}{l}\text { upper bound of the discharge uncertainty interval } \\
\text { for the XX percentile flow given as a percentage of } \\
\text { the XX percentile flow - estimates for XX values of } \\
5,25,50,75,95 \text {, and } 99 \text { are provided }\end{array}$ & $\%$ & \multirow[t]{3}{*}{$\begin{array}{lr}\text { Derived } & \text { from } \\
\text { Coxon } & \text { et } \\
\text { al. }(2015) & \end{array}$} \\
\hline & qXX_uncert_lower & $\begin{array}{l}\text { lower bound of the discharge uncertainty interval } \\
\text { for the XX percentile flow given as a percentage of } \\
\text { the XX percentile flow - estimates for XX values of } \\
5,25,50,75,95 \text {, and } 99 \text { are provided }\end{array}$ & $\%$ & \\
\hline & quncert_meta & $\begin{array}{l}\text { metadata describing the reasons why discharge un- } \\
\text { certainty estimates are (not) provided; calculated } \\
\text { discharge uncertainties; no stage-discharge mea- } \\
\text { surements available; fewer than } 20 \text { stage-discharge } \\
\text { measurements available for most recent rating; dis- } \\
\text { charge uncertainty estimates not provided as the es- } \\
\text { timated uncertainty bounds were deemed to not ac- } \\
\text { curately reflect the discharge uncertainty or because } \\
\text { there was no sensible relationship between stage } \\
\text { and discharge. }\end{array}$ & - & \\
\hline
\end{tabular}


Table 2. Continued.

\begin{tabular}{|c|c|c|c|c|}
\hline Attribute class & Attribute name & Description & Unit & Data source \\
\hline \multirow{21}{*}{$\begin{array}{l}\text { Human influ- } \\
\text { ence attributes }\end{array}$} & benchmark_catch & $\begin{array}{l}\text { benchmark catchment (Y indicates the catchment is } \\
\text { part of the UK Benchmark Network, while N indi- } \\
\text { cates that it is not) }\end{array}$ & $\mathrm{Y} / \mathrm{N}$ & $\begin{array}{l}\text { UK National } \\
\text { River Flow } \\
\text { Archive; } \\
\text { Harrigan et } \\
\text { al. (2018) }\end{array}$ \\
\hline & surfacewater_abs & mean surface water abstraction & $\mathrm{mm} \mathrm{d}^{-1}$ & \multirow{9}{*}{$\begin{array}{l}\text { Abstractions } \\
\text { and discharges } \\
\text { sourced from } \\
\text { the Environ- } \\
\text { ment Agency }\end{array}$} \\
\hline & groundwater_abs & mean groundwater abstraction & $\mathrm{mm} \mathrm{d}^{-1}$ & \\
\hline & discharges & $\begin{array}{l}\text { mean discharges (daily discharges into water } \\
\text { courses from water companies and other dis- } \\
\text { charge permit holders reported to the Environment } \\
\text { Agency) }\end{array}$ & $\mathrm{mm} \mathrm{d}^{-1}$ & \\
\hline & abs_agriculture_perc & $\begin{array}{l}\text { percentage of total (groundwater and surface water) } \\
\text { abstractions in catchment for agriculture }\end{array}$ & $\%$ & \\
\hline & abs_amenities_perc & $\begin{array}{l}\text { percentage of total (groundwater and surface water) } \\
\text { abstractions in catchment for amenities }\end{array}$ & $\%$ & \\
\hline & abs_energy_perc & $\begin{array}{l}\text { percentage of total (groundwater and surface water) } \\
\text { abstractions in catchment for energy production }\end{array}$ & $\%$ & \\
\hline & abs_environmental_perc & $\begin{array}{l}\text { percentage of total (groundwater and surface water) } \\
\text { abstractions in catchment for environmental pur- } \\
\text { poses }\end{array}$ & $\%$ & \\
\hline & abs_industry_perc & $\begin{array}{l}\text { percentage of total (groundwater and surface water) } \\
\text { abstractions in catchment for industrial, commercial } \\
\text { and public services }\end{array}$ & $\%$ & \\
\hline & abs_watersupply_perc & $\begin{array}{l}\text { percentage of total (groundwater and surface water) } \\
\text { abstractions in catchment for water supply }\end{array}$ & $\%$ & \\
\hline & num_reservoir & number of reservoirs in the catchment & - & \multirow{11}{*}{$\begin{array}{l}\text { UK Reser- } \\
\text { voir Inventory } \\
\text { (Durant and } \\
\text { Counsell, } \\
\text { 2018) and } \\
\text { SEPA's pub- } \\
\text { licly available } \\
\text { controlled } \\
\text { reservoirs } \\
\text { register } \\
\text { (http://map. } \\
\text { sepa.org.uk/ } \\
\text { reservoirsfloodmap } \\
\text { Map.htm, last } \\
\text { access: 11 De- } \\
\text { cember 2019) }\end{array}$} \\
\hline & reservoir_cap & $\begin{array}{l}\text { total storage capacity of reservoirs in the catchment } \\
\text { in megalitres }\end{array}$ & ML & \\
\hline & reservoir_he & $\begin{array}{l}\text { percentage of total reservoir storage in catchment } \\
\text { used for hydroelectricty }\end{array}$ & $\%$ & \\
\hline & reservoir_nav & $\begin{array}{l}\text { percentage of total reservoir storage in catchment } \\
\text { used for navigation }\end{array}$ & $\%$ & \\
\hline & reservoir_drain & $\begin{array}{l}\text { percentage of total reservoir storage in catchment } \\
\text { used for drainage }\end{array}$ & $\%$ & \\
\hline & reservoir_wr & $\begin{array}{l}\text { percentage of total reservoir storage in catchment } \\
\text { used for water resources }\end{array}$ & $\%$ & \\
\hline & reservoir_fs & $\begin{array}{l}\text { percentage of total reservoir storage in catchment } \\
\text { used for flood storage }\end{array}$ & $\%$ & \\
\hline & reservoir_env & $\begin{array}{l}\text { percentage of total reservoir storage in catchment } \\
\text { used for environmental }\end{array}$ & $\%$ & \\
\hline & reservoir_nousedata & $\begin{array}{l}\text { percentage of total reservoir storage in catchment } \\
\text { where no use data were available }\end{array}$ & $\%$ & \\
\hline & reservoir_year_first & year the first reservoir in the catchment was built & - & \\
\hline & reservoir_year_last & year the last reservoir in the catchment was built & - & \\
\hline
\end{tabular}



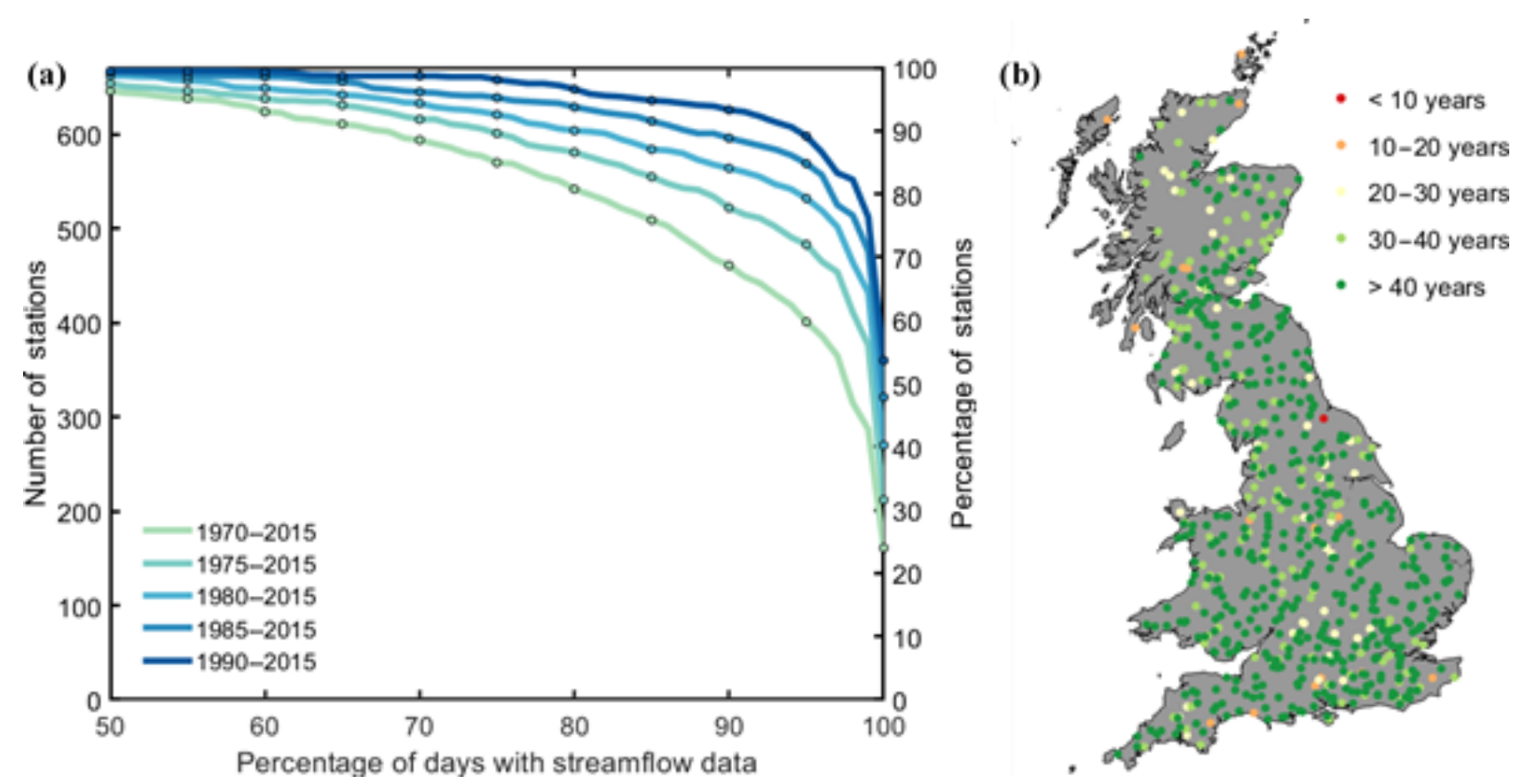

Figure 1. (a) Number of stations with percentage of available streamflow data for different periods. (b) Length of the flow time series for each gauge.

\subsection{Land cover attributes}

Land cover attributes for each catchment were derived from the UK Land Cover Map 2015 (LCM2015) produced by CEH (Rowland et al., 2017). While other land cover maps are available from CEH for 1990, 2000, and 2007, attributes are only provided for LCM2015 as different methods have been used to derive each of the land cover maps, preventing straightforward analysis of changes in land cover over time. LCM2015 was chosen as it contains the most up-todate data and methodology used to derive the land cover. LCM2015 uses a random forest classification of Landsat8 satellite images based on the Joint Nature Conservation Committee (JNCC) broad habitats, encompassing the range of UK habitats.

In this study, the $1 \mathrm{~km}$ percentage target class is used from the LCM2015 products, consisting of a $1 \mathrm{~km}$ raster with 21 bands relating to the percentage cover value of different target classes that represent broad habitats. This is a significant number of land cover classes, and so the 21 target classes were mapped to eight land cover classes: deciduous woodland, evergreen woodland, grass and pasture, shrubs, crops, suburban and urban, inland water, bare soil, and rocks (see Appendix B). These are the same as the eight land cover classes used when running the JULES model with the CHESS meteorological driving data and so provide consistency with other national-scale efforts across Great Britain (Best et al., 2011; Blyth et al., 2019; Clark et al., 2011). For each catchment, the percentage of the catchment covered by each of the eight land cover types was calculated and is pro- vided in CAMELS-GB, alongside the most dominant land cover type (see Table 2).

Key limitations of this dataset are that the land cover attributes reflect a snapshot of the land cover in time and are subject to uncertainties in the Landsat- 8 satellite images and the random forest classification. It is important to note that the land cover attributes provided in CAMELS-GB are different to those provided on the NRFA website which use LCM2000 and different land use groupings.

\subsection{Soil attributes}

Soil attributes for each catchment were derived from the European Soil Database Derived Data product (Hiederer, 2013a, b), and the modelled depth-to-bedrock global product from Pelletier et al. (2016). The European Soil Database (ESDB; European Commission Joint Research Centre, 2003) is the most detailed and comprehensive soil dataset available for Europe. It was selected for CAMELS-GB as no national soil datasets exist for GB that are both freely available and cover the same comprehensive range of soil descriptors.

As this dataset only characterises the top soil layers (up to $1.3 \mathrm{~m}$ ), we also used the Pelletier et al. (2016) modelled soil depth dataset to give an indication of the depth to unweathered bedrock extending up to $50 \mathrm{~m}$ depth. Soil attributes for depth available to roots, percentage sand, silt and clay content, organic carbon content, bulk density, and total available water content were calculated from the ESDB. We additionally estimated the saturated hydraulic conductivity and porosity (saturated volumetric water content) using 
two pedo-transfer functions, with the aim of providing one estimate consistent with CAMELS and a best estimate for European soil types. These were (1) the widely applied regressions based on sand and clay fractions first proposed by Cosby et al. (1984) based on soil samples across the United States and (2) the HYPRES continuous pedo-transfer functions using silt and clay fractions, bulk density, and organic matter content developed using a large database of European soils (Wösten et al., 1999, 2001; Wösten, 2000) (see Appendix $\mathrm{C}$ for equations).

To estimate average values of all soil properties with depth, we calculated a weighted mean of the topsoil and subsoil data for each $1 \mathrm{~km}$ grid cell. Weights were assigned based on the topsoil-subsoil proportion of the overall soil depth for that cell. Catchment-average soil properties were calculated by taking the arithmetic mean (or harmonic mean for saturated hydraulic conductivity as advised in Samaniego et al., 2010) of all $1 \mathrm{~km}$ grid cells that fell within the catchment boundaries. To give an indication of the distribution of soil properties across the catchment, the 5th, 50th, and 95th percentile values of all grid cell values falling within the catchment boundaries were also calculated for all soil attributes apart from percentage sand, silt, and clay. There were some grid cells where no soil data were available. Rather than set default values for these grid cells, we chose to exclude them from the calculations of catchment-average properties and provide the percentage of no-data cells within a catchment as an indication of the data availability of the catchmentaverage properties.

There are some key limitations associated with these datasets. Firstly, the soil information given on a $1 \mathrm{~km}$ grid is only representative of the dominant soil typological class within that area. This means that much of the soil information is not represented in the soil maps, and the variation in soil properties within the $1 \mathrm{~km}$ grid is lost. The high spatial heterogeneity of soil data means that correlations between soil property values given in the soil product and ground soil measurements are likely to be low (Hiederer, 2013a, b). Secondly, as can be seen from Fig. S12c-d, there are large uncertainties relating to the choice of pedo-transfer function. Care should be taken when interpreting results for saturated hydraulic conductivity, as the HYPRES equation is relatively inaccurate with a low $R^{2}$ value of 0.19 , and application of a single continuous pedo-transfer function may result in poor results for some soil types (Wösten et al., 2001). Finally, it is important to be aware that measured soil data were unavailable for some urban areas including London, and these areas had been gap-filled (Hiederer, 2013a, b).

\subsection{Hydrogeological attributes}

Hydrogeological attributes for each catchment were derived from the UK bedrock hydrogeological map (BGS, 2019) and a new superficial deposit productivity map, both developed by the British Geological Survey. The UK bedrock hydroge- ological map is an open-access dataset that provides detailed information (at $1: 625000$ scale) on the aquifer potential based on an attribution of lithology with seven classes of primary and secondary permeability and productivity (see Appendix $\mathrm{D}$ ). The superficial deposit productivity map is a new dataset of similarly attributed superficial deposit aquifer potential across Great Britain (at 1:625000 scale). These two datasets were chosen as they are the only two spatially continuous, consistently attributed hydrogeological maps of the bedrock and superficial deposits at the national scale for GB.

These two datasets were combined by superimposing the superficial deposit layer on top of the bedrock layer to provide catchment attributes for CAMELS-GB that characterise the uppermost geological layer (i.e. superficial deposits where present and bedrock where superficial deposits are absent). Combining the two datasets gave a total of nine hydrogeological productivity classes (see Appendix D). For each catchment, the percentage of the nine hydrogeological classes was calculated and is provided in CAMELS-GB (see Table 2). These nine classes indicate the influence of hydrogeology on river flow behaviour and describe the proportion of the catchment covered by deposits of high, moderate, or low productivity and whether this is predominantly via fracture or intergranular flow (see Table 2). Such classifications have previously been used to enable correlations between catchment hydrogeology and measures of base flow (Bloomfield et al., 2009).

Users should be aware that the aquifer productivity dataset is heuristic, based on hydrogeological inference that is based on mapped lithologies rather than on statistical analysis of borehole yields. It can be used for comparison between catchments at the regional to national scales. It should not be used at the sub-catchment scale where more refined hydrogeological information would be required to understand groundwater-surface water interactions. The hydrogeological attributes provided in CAMELS-GB will differ to those available on the NRFA website as CAMELS-GB uses the latest geological data.

\subsection{Hydrometry and discharge uncertainty}

Several attributes are provided in CAMELS-GB describing the gauging station type (i.e. the type of weir, structure, or measurement device used to measure flows) as listed on the NRFA, period of flow data available, gauging station discharge uncertainty, and channel characteristics such as bankfull (see Table 2). The catchment attributes for discharge uncertainty are described in more detail below.

\section{Discharge uncertainty estimates}

Discharge uncertainty estimates for CAMELS-GB were calculated from a large dataset of rating curves and stagedischarge measurements using a generalised framework designed to estimate place-specific discharge uncertainties out- 
lined in Coxon et al. (2015). This framework estimates discharge uncertainties using a nonparametric locally weighted regression (LOWESS). Subsets of the stage-discharge data contained within a moving window are used to calculate the mean and variance at every stage point, which then define the LOWESS-fitted rating curve and discharge uncertainty, respectively. Stage and discharge gauging uncertainties are incorporated into the framework by randomly sampling from estimated measurement error distributions to fit multiple LOWESS curves and then combining the multiple fitted LOWESS curves and variances in a Gaussian mixture model. Time-varying discharge uncertainties are accounted for by an automatic procedure where differences in historical rating curves are used to separate the stage-discharge rating data into subsets for which discharge uncertainty is estimated separately. The framework has been shown to provide robust discharge uncertainty estimates for 500 gauging stations across England and Wales (see Coxon et al., 2015, for more details).

For CAMELS-GB we extended the application of the framework to Scottish gauging stations to provide discharge uncertainty estimates across Great Britain. Discharge uncertainty estimates for CAMELS-GB catchments are provided for several flow percentiles (Q95, Q75, Q50, Q25, Q5, and $\mathrm{Q} 1$ derived from the flow time series provided in CAMELSGB described in Sect. 5.2) for the most recent rating curve to allow users to evaluate discharge uncertainty across the flow range. The upper and lower bounds of the discharge uncertainty prediction interval are provided as a percentage of the flow percentile for each catchment and flow percentile where available. In total, discharge uncertainty estimates are available for $503(75 \%)$ CAMELS-GB gauges. As the method is data based, the rating curve and its uncertainty interval cannot be computed for gauging stations where there are fewer than 20 stage-discharge measurements or for flows above (below) the highest (lowest) stage-discharge measurement. This means that for some (or all) flow percentiles (particularly Q95 and Q1) there may be no discharge uncertainty estimate as indicated by "NaN". There are 45 stations where stage-discharge data were available, but discharge uncertainty estimates are not provided as the resulting uncertainty bounds were deemed to not accurately reflect the discharge uncertainty at that gauging station or because there was no sensible relationship between stage and discharge.

Users are advised that the CAMELS-GB discharge uncertainty estimates (1) are dependent on the types of error included in and underlying assumptions of the discharge uncertainty estimation method (see Kiang et al., 2018, for a comparison of seven discharge uncertainty estimation methods) and (2) may not be applicable to the whole flow time series (as they cover the most recent rating curve) or for stations where flow is measured directly (i.e. at ultrasonic or electromagnetic stations).

\subsection{Human influences}

Providing information on the impact of humans in each catchment is a vital part of CAMELS-GB. To account for the degree of human intervention in each catchment, we compiled data on reservoirs, abstraction, and discharge returns provided by national agencies. We focused on providing quantitative data of human impacts in CAMELS-GB; however it is important to note that additional datasets are available that qualitatively characterise human impacts in GB including the Factors Affecting Runoff (FAR) codes available from the NRFA.

\subsubsection{Benchmark catchments}

Catchments are identified as being either part or not part of the UK Benchmark Network in CAMELS-GB. The UK Benchmark Network consists of 146 gauging stations that have been identified by the NRFA as suitable for the identification and interpretation of long-term hydrological variability and change against several criteria including length of record, quality of flow data, known impacts within the catchment, and expert consultation (for a full description see Harrigan et al., 2018). Consequently, these gauging stations can be treated as relatively "near-natural" and indicate that the influence of humans on the flow regimes of these catchments is modest. It is important to note that some impacts were tolerated where they were deemed to have a modest overall influence on flows and known to be stable over time. This was to ensure coverage in regions such as the heavily impacted south and east of GB.

\subsubsection{Abstraction and discharges}

The abstraction data consist of monthly abstraction data from January 1999 to December 2014 that are reported by abstraction licence holders to the Environment Agency. These data are the actual abstraction returns and represent the total volume of water removed by the licence holder for each month over the time period. A mean daily abstraction rate for all English catchments is provided in CAMELS-GB for groundwater and surface water sources. The monthly returns for each abstraction licence in the database were averaged to provide a mean monthly abstraction from 1999 to 2014. All abstraction licences that fell within each catchment boundary (using the catchment masks outlined in Sect. 4) were then summed for surface water and groundwater abstractions and converted into millimetres per day using catchment area. The mean daily abstraction rate is provided alongside attributes describing the use of the abstracted water (agriculture, amenities, environmental, industrial, energy, or water supply). The discharge data consist of daily discharges into water courses from water companies and other discharge permit holders reported to the Environment Agency from 1 January 2005 to 31 December 2015 . To calculate a mean daily discharge rate for each catchment, the daily discharge data 
for each discharge record were averaged, and then all discharge records that fell within the catchment boundary were summed and then converted into millimetres per day using catchment area.

There are several important caveats associated with these data. Firstly, these data are only available for England. Consequently, there are many catchments where no data are available (identified by "NaN"), and only a proportion of the abstractions may have been accounted for catchments which lie on the border of England-Wales or England-Scotland. Furthermore, not all licence types/holders are required to submit records to the Environment Agency; therefore this is not the full picture of human intervention within each catchment. Secondly, the abstraction and discharge data cover different time periods. Thirdly, the topographical catchment mask was used to define which abstraction returns were included in each catchment. Groundwater abstractions that lie within the topographical catchment may not have a direct impact on the catchment streamflow and instead may impact a neighbouring catchment that shares the same aquifer. Conversely, groundwater abstractions that lie outside the catchment could have an impact on the catchment streamflow. Fourthly, there is large inter-annual and intra-annual variation in the abstraction and discharge data, and its impacts will be different across the flow regime. Consequently, it is important that the mean abstraction totals are used as a guide to the degree of human intervention in each catchment rather than absolute totals of the abstraction for any given month. Finally, although "abstractions" represent removed water from surface water or groundwater sources, some of this water will be returned to catchment storages. The discharge data provided account just for treated water from sewage treatment works and do not provide information on other water returns that may be fed back into catchment storages. The mean totals for abstractions and discharges are a very broad guide that point to the possible influence of abstractions but do not quantify the net influence of these impacts on the actual flow regime. Other (less widely available) metrics have been applied in the UK which use modelling approaches to assess the net impact of abstractions/discharges across the whole flow regime (for example the LowFlows Enterprise methodology; see also Hannaford et al., 2013).

\subsubsection{Reservoirs}

Reservoir attributes are derived from an open-source UK reservoir inventory (Durant and Counsell, 2018) supplemented with information from SEPA's publicly available controlled reservoirs register. The UK reservoir inventory includes reservoirs above 1600 megalitre (ML) capacity, covering approximately $90 \%$ of the total reservoir storage in the UK. This dataset was collected from the Environment Agency through a freedom of information request, the UK Lakes Portal (CEH), and subsequent internet searches. It includes information on the location of the reservoir, its ca- pacity, use, and the year the reservoir was built. To check the accuracy of this dataset, we cross-referenced the reservoirs in the UK reservoir inventory with reservoirs in the Global Reservoir and Dam (GRanD v1.3) database (Lehner et al., 2011). While many of the reservoirs and their capacity data were consistent for reservoirs for England and Wales, many Scottish reservoirs contained in the GRanD database were not present in the UK reservoir inventory or reported very different storage capacities. This is likely due to the estimation of storage capacities of Scottish reservoirs in the UK reservoir inventories (see Hughes et al., 2004) rather than actual storage capacities. Consequently, for reservoirs in Scotland, we used information from SEPA's publicly available controlled reservoir register (http://map.sepa. org.uk/reservoirsfloodmap/Map.htm, last access: 11 December 2019) including the reservoir name, location, and storage capacity. Then we supplemented this information with the year the reservoir was built and reservoir use by crossreferencing data from the UK reservoir inventory (users should be aware that reservoir use and the year the reservoir was built were not available for every reservoir).

For CAMELS-GB several reservoir attributes are derived for each catchment by determining the reservoirs that lie within the catchment mask from the reservoir locations and then calculating (1) the number of reservoirs in each catchment; (2) their combined capacity, (3) the fraction of that capacity that is used for hydroelectricity, navigation, drainage, water supply, flood storage, and environmental purposes; and (4) the year when the first and last reservoirs in the catchment were built.

\subsection{Regional variability in catchment characteristics}

Figure 2 highlights some of the key catchment variables, and in this section we discuss their regional variability (according to the regions in Fig. 2a). Spatial maps of all catchment attributes can be found in Figs. S4-S11.

There are distinct regional differences in climate across GB (Fig. 2b). Precipitation is typically higher in the west and north of GB corresponding with the areas of high elevation and prevailing winds from the west that bring significant rainfall. The wettest areas of the UK are in mountainous regions with a maximum of $9.6 \mathrm{~mm} \mathrm{~d}^{-1}$ (annual average of $3500 \mathrm{~mm} \mathrm{yr}^{-1}$ ) in the north-west. Snow fractions are generally very low across Great Britain (median snow fraction of 0.01) except for catchments in the Cairngorm mountains in north-east Scotland where the fraction of precipitation falling as snow can reach 0.17 (see Fig. S5e). Precipitation is lowest in the south and east of GB with a minimum of $1.5 \mathrm{~mm} \mathrm{~d}^{-1}$ in the east. In contrast, potential evapotranspiration (PET) is much less variable across GB, with mean daily totals ranging from 1 to $1.5 \mathrm{~mm} \mathrm{~d}^{-1}$. PET is highest in the south (where temperatures are highest) and lowest in the north. Mean flow varies from 10 to $0.09 \mathrm{~mm} \mathrm{~d}^{-1}$ and is typically higher in the north and west, reflecting the regional 
(a)

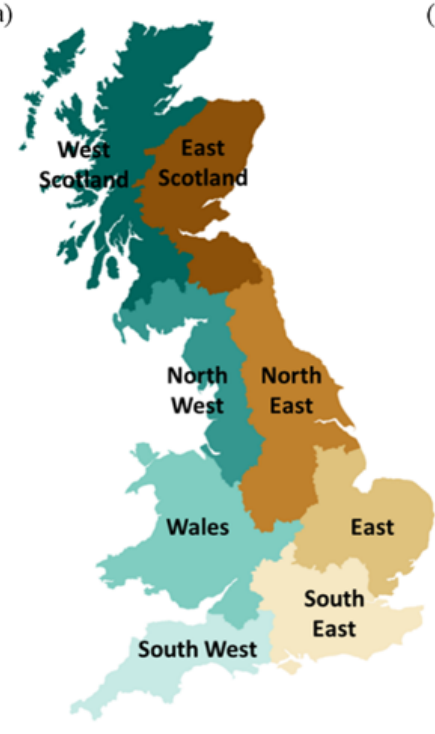

(b)

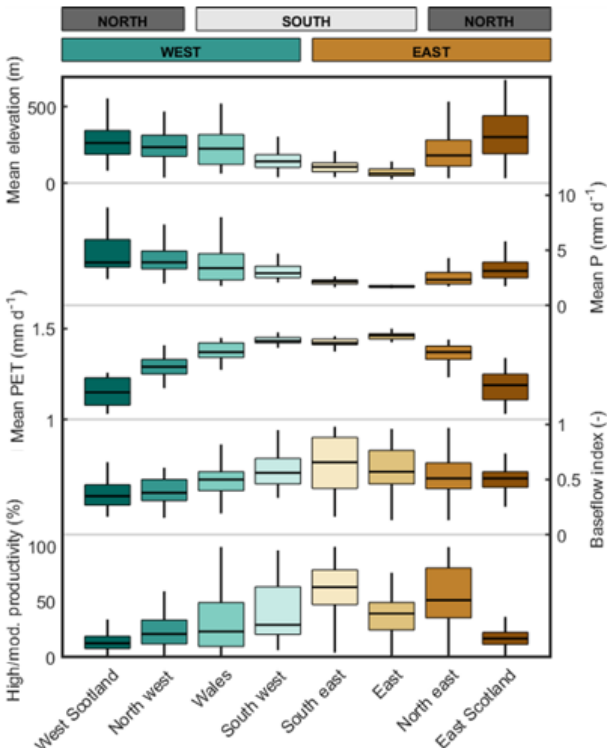

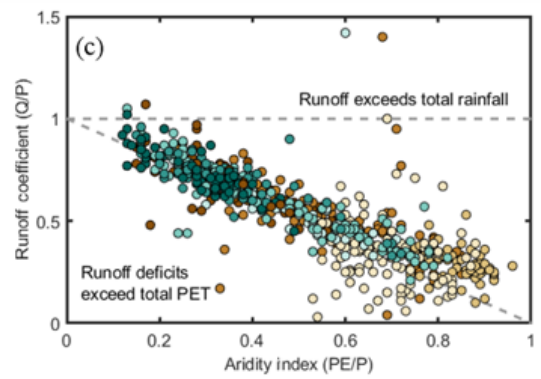
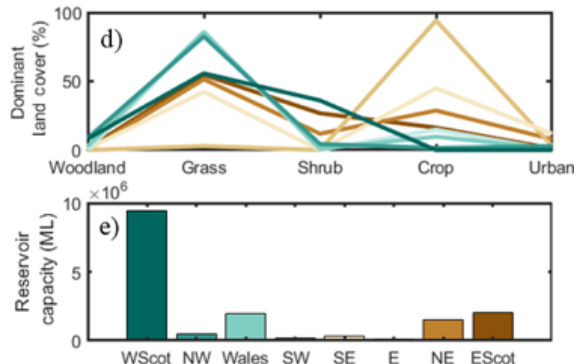

Figure 2. Key catchment variables. (a) Map of Great Britain river basin regions based on the UKCP09 river basins aggregated from 21 river basin districts to eight regions. (b) Box plots showing the range of key climatic, hydrology, and hydrogeologic (defined by the proportion of the catchment underlain by high or moderate productivity aquifers) catchment attributes for each region. (c) Budyko-type curve relating runoff coefficient to aridity index; points are coloured by region, and the $y$ axis is limited to 1.5, which means two gauges (26006 and 27038 ) are not shown that have a runoff coefficient of 3. (d) The percentage of catchments in each region with a dominant land cover of either woodland (evergreen and deciduous), grass, shrub, crop, or urban. (e) The total reservoir capacity in the catchments in each region.

variability in precipitation and PET. This is also reflected in Fig. 2c, where catchments in the north and west of GB tend to be wetter with higher runoff coefficients, and catchments in the south and east are much drier with lower runoff coefficients. Figure $2 \mathrm{c}$ also shows that annual precipitation totals exceed annual PET totals; the aridity index is below 1 for all catchments, reflecting the temperate and humid climate of GB. It is important to note that these estimates are dependent on the underlying data. For example, there can be significant variability in the calculation of PET, depending on the methods and assumptions used (e.g. Tanguy et al., 2018), and here we have used a PET estimate where canopy interception is not accounted for. Interception is an important component of the water cycle in GB, which experiences a large amount of low to moderate rainfall intensities (Blyth et al., 2019). Thus using the CHESS PETI estimate would instead increase the aridity index above 1 in some locations.

There is also regional variability in base flow index (the ratio of mean daily base flow to daily discharge), which is typically higher in the south and east of GB and lower in the north-west. Some of these differences can be attributed to regional aquifers that have high/moderate productivity which are more prevalent in the south-east, east, and north-east (see Fig. 2b).

From Fig. 2c, it is notable that runoff deficits significantly exceed total potential evapotranspiration for many of the CAMELS-GB catchments in the south-east - this could be due to water loss to regional aquifers, the issue of catch- ment areas not mapping onto the contributing area, and/or the choice of PET used (see above). There are also seven catchments where the runoff exceeds total rainfall - this could be due to water gains from regional aquifers, catchment areas not mapping onto the contributing area, inter-basin transfers, and/or under-estimation of rainfall. Many of the widely used hydrological models and analysis techniques will not be able to reproduce catchment water balances which are outside the water and energy limitations shown in Fig. 2c, unless the models or analysis techniques are explicitly adapted to consider the sources of uncertainty, potential unmeasured groundwater flow pathways, and/or human influences that we have noted. We encourage users of the data to consider whether the assumptions of their methods are consistent with the uncertainties we have documented.

Land cover and human modifications can also impact river flows. Crops and grassland tend to be the dominant land cover for GB catchments, with crops typically being the dominant land cover for catchments in the east and grassland for catchments in the west (Fig. 2d). There is also a higher percentage of catchments in the east which are dominated by urban land cover. Large reservoir capacity is concentrated in the more mountainous northern and western regions of GB, particularly in western Scotland (Fig. 2e). 


\section{Data availability}

The CAMELS-GB dataset (Coxon et al., 2020) detailed in this paper is freely available via the UK Centre for Ecology \& Hydrology Environmental Information Data Centre (https://doi.org/10.5285/8344e4f3-d2ea-44f58afa-86d2987543a9). The data contain catchment masks, catchment time series, and catchment attributes as described above. A full description of the data format is provided in the supporting documentation available on the Environmental Information Data Centre.

\section{Conclusions}

This study introduces the first large-sample, open-source catchment dataset for Great Britain, CAMELS-GB (Catchment Attributes and MEteorology for Large-sample Studies), consisting of hydro-meteorological catchment time series, catchment attributes, and catchment boundaries for 671 catchments. A comprehensive set of catchment attributes is quantified describing a range of catchment characteristics including topography, climate, hydrology, land cover, soils, and hydrogeology. Importantly, we also derive attributes describing the level of human influence in each catchment and the first set of national discharge uncertainty estimates that quantify discharge uncertainty across the flow range.

The dataset provides new opportunities to explore how different catchment characteristics control river flow behaviour, develop common frameworks for model evaluation and benchmarking at regional-national scales, and analyse hydrologic variability across the UK. To ensure the reproducibility of the dataset, many of the codes and datasets are made available to users.

While a wealth of data are provided in CAMELS-GB, there are many opportunities to expand the dataset that were outside the scope of this study. Currently there are no plans to regularly update CAMELS-GB; however, future work will concentrate on (1) expanding the dataset to include higherresolution data (such as hourly rainfall, e.g. Lewis et al., 2018, and flow time series) and datasets for the analysis of trends (such as changes in land cover over time), and (2) refining the characterisation of uncertainties in catchment attributes and forcing (particularly for rainfall data). We are also striving to increase the consistency among the CAMELS datasets (in terms of time series, catchment attributes, naming conventions, and data format; see Addor et al., 2019) and to create a dataset that is globally consistent. We anticipate that this will happen as part of a second phase, which will build upon the current first phase that is focussed on the release of national products, such as CAMELS-GB. 


\section{Appendix A: A base flow index}

The base flow separation followed the Manual on Low-flow Estimation and Prediction of the World Meteorological Organization (2008). It relies on identifying local minima in daily streamflow series and producing a continuous base flow hydrograph by linear interpolation between the identified local streamflow minima. The base flow separation was performed using the R package lfstat (Koffler et al., 2016). The streamflow minima were identified using non-overlapping periods of $N=5$ (block size) consecutive days and $f=0.9$ as the turning point parameter value.

\section{Appendix B: Land cover classes}

We used the following classification to map the 21 land cover classes contained in the UK Land Cover Map 2015 to the eight land cover classes used in CAMELS-GB.

Table B1. Band ID and name from Land Cover Map (LCM) 2015 and corresponding land cover classes used in CAMELS-GB.

\begin{tabular}{lll}
\hline Band & LCM2015 band name & CAMELS-GB land cover classes \\
\hline 1 & Broadleaved woodland & Deciduous woodland \\
2 & Coniferous woodland & Evergreen woodland \\
3 & Arable and horticulture & Crops \\
4 & Improved grassland & Grass and pasture \\
5 & Neutral grassland & Grass and pasture \\
6 & Calcareous grassland & Grass and pasture \\
7 & Acid grassland & Grass and pasture \\
8 & Fen, marsh, and swamp & Grass and pasture \\
9 & Heather & Medium-scale vegetation (shrubs) \\
10 & Heather grassland & Medium-scale vegetation (shrubs) \\
11 & Bog & Medium-scale vegetation (shrubs) \\
12 & Inland Rock & Bare soil and rocks \\
13 & Saltwater & Not classified \\
14 & Freshwater & Inland water \\
15 & Supralittoral rock & Bare soil and rocks \\
16 & Supralittoral sediment & Bare soil and rocks \\
17 & Littoral rock & Not classified \\
18 & Littoral sediment & Not classified \\
19 & Salt marsh & Inland water \\
20 & Urban & Urban and suburban \\
21 & Suburban & Urban and suburban \\
\hline & &
\end{tabular}




\section{Appendix C: Soil pedo-transfer functions}

We estimated the saturated hydraulic conductivity and porosity (also referred to as maximum water content, saturated water content, satiated water content) using two pedo-transfer functions.

The first was the widely applied regressions based on sand and clay fractions first proposed by Cosby et al. (1984):

$K_{\mathrm{s}}=2.54 * 10^{-0.6+0.012 \mathrm{Sa}-0.0064 \mathrm{Cl}}$

$\theta_{\mathrm{s}}=50.5-0.142 \mathrm{Sa}-0.037 \mathrm{Cl}$,

where $K_{\mathrm{S}}$ is saturated hydraulic conductivity in centimetres per hour and $\theta_{\mathrm{S}}$ is porosity in percent $\left(\mathrm{m}^{3} \mathrm{~m}^{-3}\right)$. Predictor variables are sand $(\mathrm{Sa})$ and clay $(\mathrm{Cl})$.

The second was the HYPRES continuous pedo-transfer functions using silt and clay fractions, bulk density, and organic matter content (Wösten et al., 1999; Wösten, 2000).

$$
\begin{gathered}
\left(7.755+0.0352 \mathrm{Si}+0.93 \mathrm{Tp}-0.967 \mathrm{Db}^{2}\right. \\
-0.000484 \mathrm{Cl}^{2}-0.000322 \mathrm{Si}^{2}+0.001 \mathrm{is}^{-1} \\
-0.0748 \mathrm{Om}^{-1}-0.643 \ln (\mathrm{Si})-0.01398 \mathrm{DbCl} \\
K_{\mathrm{S}}=0.04167 e^{-0.1673 \mathrm{DbOm}+0.02986 \mathrm{TpCl}-0.03305 \mathrm{TpSi})} \\
\theta_{\mathrm{S}}=0.7919+0.001691 \mathrm{Cl}-0.29619 \mathrm{Db}-0.000001491 \mathrm{Si}^{2} \\
+0.0000821 \mathrm{Om}^{2}+0.02427 \mathrm{Cl}^{-1}+0.01113 \mathrm{Si}^{-1} \\
+0.01472 \ln (\mathrm{Si})-0.0000733 \mathrm{OmCl}-0.000619 \mathrm{DbCl} \\
-0.001183 \mathrm{DbOm}-0.0001664 \mathrm{TpSi}
\end{gathered}
$$

Here $K_{\mathrm{S}}$ is saturated hydraulic conductivity in centimetre per hour and $\theta_{\mathrm{s}}$ is porosity $\left(\mathrm{m}^{3} \mathrm{~m}^{-3}\right)$. Predictor variables are sand $(\mathrm{Sa})$ and clay $(\mathrm{Cl})$. Predictor variables are percentage silt $(\mathrm{Si})$, percentage clay $(\mathrm{Cl})$, percentage organic matter $(\mathrm{Om})$, bulk density $(\mathrm{Db})$, and a binary variable for topsoil (Tp). 


\section{Appendix D: Hydrogeological classes}

For CAMELS-GB, we combined the BGS hydrogeology map and superficial deposit layer. The table below provides a summary of the different classes in each dataset and how these were amalgamated to form the nine classes used in CAMELS-GB.

Table D1. Data source, class, and description of the hydrogeological datasets.

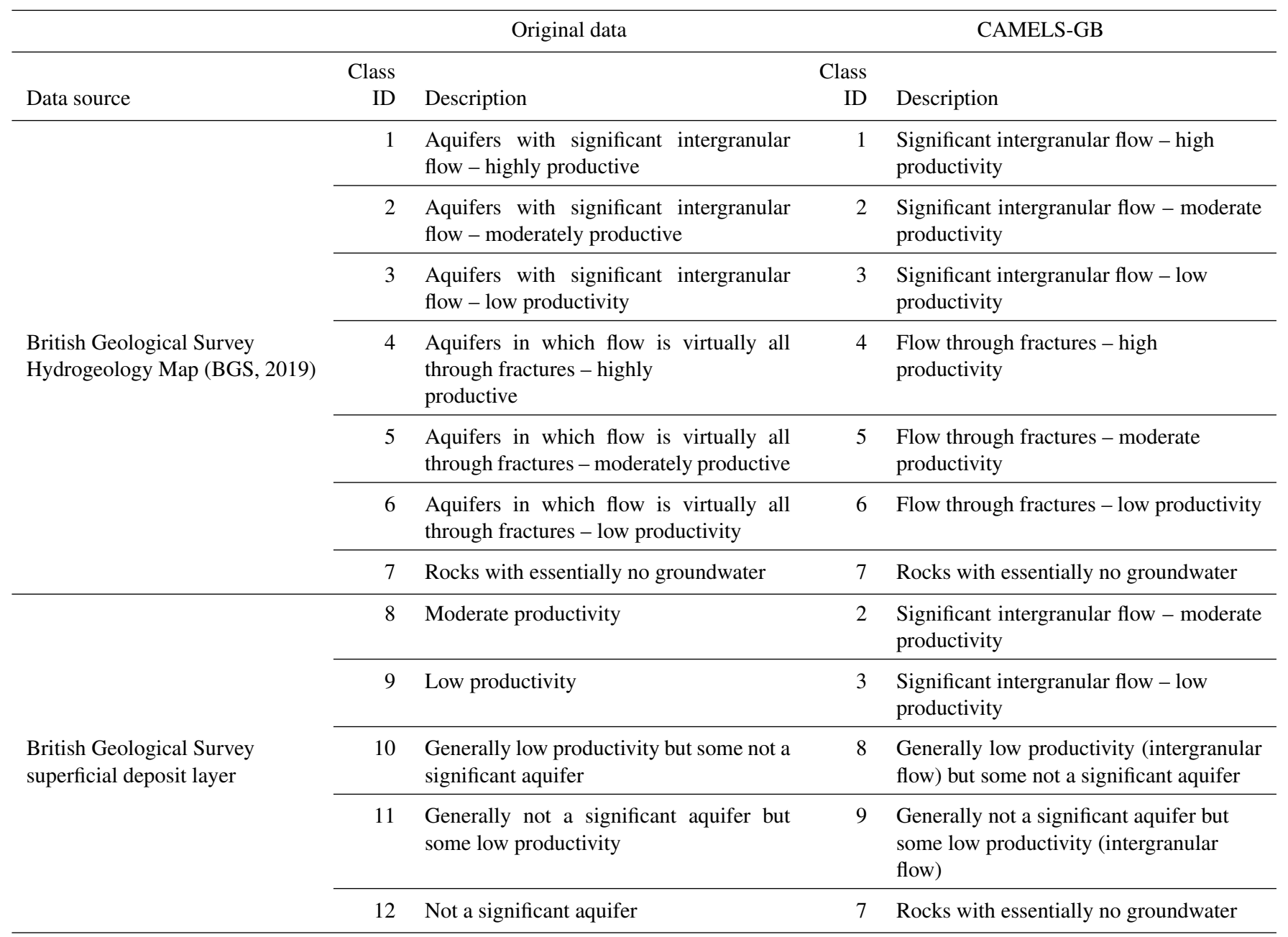


Supplement. The supplement related to this article is available online at: https://doi.org/10.5194/essd-12-2459-2020-supplement.

Author contributions. GC initiated and led the project. GC produced the CAMELS-GB dataset with the following contributions. (1) NA derived the climatic indices and hydrologic signatures, (2) RL derived the soil attributes, (3) ML derived the superficial deposit geological layer and provided guidance with JPB on deriving the hydrogeological attributes, (4) ELR provided guidance on the meteorological datasets (CHESS-met and CHESS-PE) and mapping the land cover data, and (5) MF provided the streamflow data, catchment masks, and all catchment attributes sourced from the National River Flow Archive. All co-authors contributed to the design of the dataset. The manuscript was prepared by GC with contributions from all co-authors.

Competing interests. The authors declare that they have no conflict of interest.

Acknowledgements. The authors would like to express their great appreciation to all the data collectors, processors, and providers who made this work possible, particularly at the UK Centre for Ecology \& Hydrology, the National River Flow Archive, UK Met Office, Environment Agency, Natural Resources Wales, and Scottish Environmental Protection Agency.

The authors also gratefully acknowledge the help of Sebastian Gnann and Melike Kiraz for being the first to use CAMELS-GB and providing helpful comments from a data user perspective.

This work was initially started and inspired by the UK Environmental Virtual Observatory Project (EVOp), grant number NE/1002200/1. Gemma Coxon, Jim Freer, Thorsten Wagener, Ross Woods, and Nicholas J. K. Howden were supported by NERC MaRIUS: Managing the Risks, Impacts and Uncertainties of droughts and water Scarcity, grant number NE/L010399/1. Rosanna Lane was funded as part of the Water Informatics Science and Engineering Centre for Doctoral Training (WISE CDT) under a grant from the Engineering and Physical Sciences Research Council (EPSRC), grant number EP/L016214/1. Nans Addor was supported by the Swiss National Science Foundation (P400P2_180791). Matt Fry and Jamie Hannaford were funded by the National Environment Research Council as part of the national capability programmes Hydro-JULES (award number NE/S017380/1) and UKSCAPE (NE/R016429/1).

John P. Bloomfield and Melinda Lewis publish with permission of the Executive Director, British Geological Survey (NERC/UKRI).

This study is a contribution to the large-sample hydrology working group of the Panta Rhei research initiative of the International Association of Hydrological Sciences (IAHS).

Financial support. This research has been supported by the Natural Environment Research Council (grant nos. NE/L010399/1, NE/1002200/1, NE/S017380/1, and NE/R016429/1), the Engineering and Physical Sciences Research Council (grant no. EP/L016214/1), and the Swiss National Science Foundation (grant no. P400P2_180791).

Review statement. This paper was edited by Alexander Gelfan and reviewed by two anonymous referees.

\section{References}

Addor, N., Newman, A. J., Mizukami, N., and Clark, M. P.: The CAMELS data set: catchment attributes and meteorology for large-sample studies, Hydrol. Earth Syst. Sci., 21, 5293-5313, https://doi.org/10.5194/hess-21-5293-2017, 2017.

Addor, N., Nearing, G., Prieto, C., Newman, A. J., Le Vine, N., and Clark, M. P.: A Ranking of Hydrological Signatures Based on Their Predictability in Space, Water Resour. Res., 54, 87928812, https://doi.org/10.1029/2018WR022606, 2018.

Addor, N., Do, H. X., Alvarez-Garreton, C., Coxon, G., Fowler, K., and Mendoza, P. A.: Large-sample hydrology: recent progress, guidelines for new datasets and grand challenges, Hydrol. Sci. J., 0, 1-14, https://doi.org/10.1080/02626667.2019.1683182, 2019.

Allen, R. G., Pereira, L. S., Raes, D., and Smith, M.: Crop evapotranspiration - Guidelines for computing crop water requirements, Food and Agriculture Organization of the United Nations, Rome, available at: http://www.fao.org/3/X0490E/X0490E00. htm (last access: 7 October 2019), 1998

Alvarez-Garreton, C., Mendoza, P. A., Boisier, J. P., Addor, N., Galleguillos, M., Zambrano-Bigiarini, M., Lara, A., Puelma, C., Cortes, G., Garreaud, R., McPhee, J., and Ayala, A.: The CAMELS-CL dataset: catchment attributes and meteorology for large sample studies - Chile dataset, Hydrol. Earth Syst. Sci., 22 5817-5846, https://doi.org/10.5194/hess-22-5817-2018, 2018.

Ames, D. P., Horsburgh, J. S., Cao, Y., Kadlec, J., Whiteaker, T., and Valentine, D.: HydroDesktop: Web services-based software for hydrologic data discovery, download, visualization, and analysis, Environ. Model. Softw., 37, 146-156, https://doi.org/10.1016/j.envsoft.2012.03.013, 2012.

Arsenault, R., Bazile, R., Dallaire, C. O., and Brissette, F.: CANOPEX: A Canadian hydrometeorological watershed database, Hydrol. Process., 30, 2734-2736, https://doi.org/10.1002/hyp.10880, 2016.

Bayliss, A.: Flood estimation handbook: Catchment descriptors, Institute of Hydrology, 1999.

Berghuijs, W. R., Aalbers, E. E., Larsen, J. R., Trancoso, R., and Woods, R. A.: Recent changes in extreme floods across multiple continents, Environ. Res. Lett., 12, 114035, https://doi.org/10.1088/1748-9326/aa8847, 2017.

Best, M. J., Pryor, M., Clark, D. B., Rooney, G. G., Essery, R. L. H., Ménard, C. B., Edwards, J. M., Hendry, M. A., Porson, A., Gedney, N., Mercado, L. M., Sitch, S., Blyth, E., Boucher, O., Cox, P. M., Grimmond, C. S. B., and Harding, R. J.: The Joint UK Land Environment Simulator (JULES), model description Part 1: Energy and water fluxes, Geosci. Model Dev., 4, 677-699, https://doi.org/10.5194/gmd-4-677-2011, 2011.

Beven, K.: A sensitivity analysis of the Penman-Monteith actual evapotranspiration estimates, J. Hydrol., 44, 169-190, https://doi.org/10.1016/0022-1694(79)90130-6, 1979. 
BGS: BGS hydrogeology 625k, available at: https://www.bgs.ac.uk/ products/hydrogeology/maps.html, last access: 8 October 2019.

Bloomfield, J. P., Allen, D. J., and Griffiths, K. J.: Examining geological controls on baseflow index (BFI) using regression analysis: An illustration from the Thames Basin, UK, J. Hydrol., 373, 164-176, https://doi.org/10.1016/j.jhydrol.2009.04.025, 2009.

Blöschl, G., Hall, J., Parajka, J., Perdigão, R. A. P., Merz, B., Arheimer, B., Aronica, G. T., Bilibashi, A., Bonacci, O., Borga, M., Čanjevac, I., Castellarin, A., Chirico, G. B., Claps, P., Fiala, K., Frolova, N., Gorbachova, L., Gül, A., Hannaford, J., Harrigan, S., Kireeva, M., Kiss, A., Kjeldsen, T. R., Kohnová, S., Koskela, J. J., Ledvinka, O., Macdonald, N., MavrovaGuirguinova, M., Mediero, L., Merz, R., Molnar, P., Montanari, A., Murphy, C., Osuch, M., Ovcharuk, V., Radevski, I., Rogger, M., Salinas, J. L., Sauquet, E., Šraj, M., Szolgay, J., Viglione, A., Volpi, E., Wilson, D., Zaimi, K., and Živković, N.: Changing climate shifts timing of European floods, Science, 357, 588-590, https://doi.org/10.1126/science.aan2506, 2017.

Blyth, E. M., Martínez-de la Torre, A., and Robinson, E. L.: Trends in evapotranspiration and its drivers in Great Britain: 1961 to 2015, Prog. Phys. Geogr. Earth Environ., 43, 666-693, https://doi.org/10.1177/0309133319841891, 2019.

Brantley, S. L., McDowell, W. H., Dietrich, W. E., White, T. S., Kumar, P., Anderson, S. P., Chorover, J., Lohse, K. A., Bales, R. C., Richter, D. D., Grant, G., and Gaillardet, J.: Designing a network of critical zone observatories to explore the living skin of the terrestrial Earth, Earth Surf. Dynam., 5, 841-860, https://doi.org/10.5194/esurf-5-841-2017, 2017.

Buytaert, W., Reusser, D., Krause, S., and Renaud, J.-P.: Why can't we do better than Topmodel?, Hydrol. Process., 22, 4175-4179, https://doi.org/10.1002/hyp.7125, 2008.

Ceola, S., Arheimer, B., Baratti, E., Blöschl, G., Capell, R., Castellarin, A., Freer, J., Han, D., Hrachowitz, M., Hundecha, Y., Hutton, C., Lindström, G., Montanari, A., Nijzink, R., Parajka, J., Toth, E., Viglione, A., and Wagener, T.: Virtual laboratories: new opportunities for collaborative water science, Hydrol. Earth Syst. Sci., 19, 2101-2117, https://doi.org/10.5194/hess-19-2101-2015, 2015.

Clark, D. B., Mercado, L. M., Sitch, S., Jones, C. D., Gedney, N., Best, M. J., Pryor, M., Rooney, G. G., Essery, R. L. H., Blyth, E., Boucher, O., Harding, R. J., Huntingford, C., and Cox, P. M.: The Joint UK Land Environment Simulator (JULES), model description - Part 2: Carbon fluxes and vegetation dynamics, Geosci. Model Dev., 4, 701-722, https://doi.org/10.5194/gmd-4701-2011, 2011.

Clausen, B. and Biggs, B. J. F.: Flow variables for ecological studies in temperate streams: groupings based on covariance, J. Hydrol., 237, 184-197, https://doi.org/10.1016/S0022-1694(00)00306-1, 2000.

Coron, L., Andréassian, V., Perrin, C., Lerat, J., Vaze, J., Bourqui, M., and Hendrickx, F.: Crash testing hydrological models in contrasted climate conditions: An experiment on 216 Australian catchments, Water Resour. Res., 48, W05552, https://doi.org/10.1029/2011WR011721, 2012.

Cosby, B. J., Hornberger, G. M., Clapp, R. B., and Ginn, T. R.: A Statistical Exploration of the Relationships of Soil Moisture Characteristics to the Physical Properties of Soils, Water Resour. Res., 20, 682-690, https://doi.org/10.1029/WR020i006p00682, 1984.
Coxon, G., Freer, J., Wagener, T., Odoni, N. A., and Clark, M.: Diagnostic evaluation of multiple hypotheses of hydrological behaviour in a limits-of-acceptability framework for 24 UK catchments, Hydrol. Process., 28, 6135-6150, https://doi.org/10.1002/hyp.10096, 2014.

Coxon, G., Freer, J., Westerberg, I. K., Wagener, T., Woods, R., and Smith, P. J.: A novel framework for discharge uncertainty quantification applied to $500 \mathrm{UK}$ gauging stations, Water Resour. Res., 51, 5531-5546, https://doi.org/10.1002/2014WR016532, 2015.

Coxon, G., Freer, J., Lane, R., Dunne, T., Knoben, W. J. M., Howden, N. J. K., Quinn, N., Wagener, T., and Woods, R.: DECIPHeR v1: Dynamic fluxEs and ConnectIvity for Predictions of HydRology, Geosci. Model Dev., 12, 2285-2306, https://doi.org/10.5194/gmd-12-2285-2019, 2019.

Coxon, G., Addor, N., Bloomfield, J. P., Freer, J. E., Fry, M., Hannaford, J., Howden, N. J. K., Lane, R., Lewis, M., Robinson, E. L., Wagener, T., and Woods, R.: Catchment attributes and hydro-meteorological timeseries for 671 catchments across Great Britain (CAMELS-GB), NERC Environ. Inf. Data Cent., https://doi.org/10.5285/8344e4f3-d2ea-44f58afa-86d2987543a9, 2020.

Dixon, H., Hannaford, J., and Fry, M. J.: The effective management of national hydrometric data: experiences from the United Kingdom, Hydrol. Sci. J., 58, 1383-1399, https://doi.org/10.1080/02626667.2013.787486, 2013.

Do, H. X., Gudmundsson, L., Leonard, M., and Westra, S.: The Global Streamflow Indices and Metadata Archive (GSIM) - Part 1: The production of a daily streamflow archive and metadata, Earth Syst. Sci. Data, 10, 765-785, https://doi.org/10.5194/essd10-765-2018, 2018.

Duan, Q., Schaake, J., Andréassian, V., Franks, S., Goteti, G., Gupta, H. V., Gusev, Y. M., Habets, F., Hall, A., Hay, L., Hogue, T., Huang, M., Leavesley, G., Liang, X., Nasonova, O. N., Noilhan, J., Oudin, L., Sorooshian, S., Wagener, T., and Wood, E. F.: Model Parameter Estimation Experiment (MOPEX): An overview of science strategy and major results from the second and third workshops, J. Hydrol., 320, 3-17, https://doi.org/10.1016/j.jhydrol.2005.07.031, 2006.

Durant, M. J. and Counsell, C. J.: Inventory of reservoirs amounting to $90 \%$ of total UK storage, NERC Environ. Inf. Data Cent., https://doi.org/10.5285/f5a7d56c-cea0-4f00-b159c3788a3b2b38, 2018.

Emmett, B., Gurney, R. J., McDonald, A. T., Blair, G., Buytaert, W., Freer, J., Haygarth, P., Johnes, P. J., Rees, G. H., Tetzlaff, D., Afgan, E., Ball, L. A., Beven, K., Bick, M., Bloomfield, J., Brewer, P., Delve, J., El-khatib, Y., Field, D., Gemmell, A. L., Greene, S., Huntingford, C., Mackay, E., Macklin, M. V., MacLeod, K., Marshall, K. E., Odoni, N., Percy, B. J., Quinn, P. F., Reaney, S., Stutter, M., Surajbali, B., Thomas, N. R., Vitolo, C., Williams, B. L., Wilkinson, M., and Zelazowski, P.: Environmental Virtual Observatory: Final Report, available at: https://researchinformation.bris.ac.uk/en/publications/environmentalvirtual-observatory(32e19260-0aae-44fb-a6be-

7eeecc497aaa)/export.html (last access: 12 December 2019), 2014.

Falkenmark, M. and Chapman, T. G.: Comparative Hydrology: An Ecological Approach to Land and Water Resources, Unesco, 1989. 
Folland, C. K., Hannaford, J., Bloomfield, J. P., Kendon, M., Svensson, C., Marchant, B. P., Prior, J., and Wallace, E.: Multi-annual droughts in the English Lowlands: a review of their characteristics and climate drivers in the winter half-year, Hydrol. Earth Syst. Sci., 19, 2353-2375, https://doi.org/10.5194/hess-19-23532015, 2015.

Fowler, K. J. A., Peel, M. C., Western, A. W., Zhang, L., and Peterson, T. J.: Simulating runoff under changing climatic conditions: Revisiting an apparent deficiency of conceptual rainfall-runoff models, Water Resour. Res., 52, 1820-1846, https://doi.org/10.1002/2015WR018068, 2016.

Gnann, S. J., Woods, R. A., and Howden, N. J. K.: Is There a Baseflow Budyko Curve?, Water Resour. Res., 55, 2838-2855, https://doi.org/10.1029/2018WR024464, 2019.

Gudmundsson, L., Do, H. X., Leonard, M., and Westra, S.: The Global Streamflow Indices and Metadata Archive (GSIM) - Part 2: Quality control, time-series indices and homogeneity assessment, Earth Syst. Sci. Data, 10, 787-804, https://doi.org/10.5194/essd-10-787-2018, 2018.

Gudmundsson, L., Leonard, M., Do, H. X., Westra, S., and Seneviratne, S. I.: Observed Trends in Global Indicators of Mean and Extreme Streamflow, Geophys. Res. Lett., 46, 756-766, https://doi.org/10.1029/2018GL079725, 2019.

Gupta, H. V., Perrin, C., Blöschl, G., Montanari, A., Kumar, R., Clark, M., and Andréassian, V.: Large-sample hydrology: a need to balance depth with breadth, Hydrol. Earth Syst. Sci., 18, 463477, https://doi.org/10.5194/hess-18-463-2014, 2014

Gustard, A., Bullock, A., and Dixon, J. M.: Low flow estimation in the United Kingdom, available at: http://nora.nerc.ac.uk/id/ eprint/6050/ (last access: 12 December 2019), 1992.

Hannaford, J.: Development of a strategic data management system for a national hydrological database, the uk national river flow archive, in Hydroinformatics, 637-644, World Scientific Publishing Company., 2004.

Hannaford, J. and Buys, G.: Trends in seasonal river flow regimes in the UK, J. Hydrol., 475, 158-174, https://doi.org/10.1016/j.jhydrol.2012.09.044, 2012.

Hannaford, J. and Marsh, T.: An assessment of trends in UK runoff and low flows using a network of undisturbed catchments, Int. J. Climatol., 26, 1237-1253, https://doi.org/10.1002/joc.1303, 2006.

Hannaford, J., Holmes, M. G. R., Laizé, C. L. R., Marsh, T. J., and Young, A. R.: Evaluating hydrometric networks for prediction in ungauged basins: a new methodology and its application to England and Wales, Hydrol. Res., 44, 401-418, doi:10.2166/nh.2012.115, 2013.

Hannah, D. M., Demuth, S., Lanen, H. A. J. van, Looser, U., Prudhomme, C., Rees, G., Stahl, K., and Tallaksen, L. M.: Large-scale river flow archives: importance, current status and future needs, Hydrol. Process., 25, 1191-1200, https://doi.org/10.1002/hyp.7794, 2011

Harrigan, S., Hannaford, J., Muchan, K., and Marsh, T. J.: Designation and trend analysis of the updated UK Benchmark Network of river flow stations: the UKBN2 dataset, Hydrol. Res., 49, 552567, https://doi.org/10.2166/nh.2017.058, 2018.

Hiederer, R.: Mapping Soil Properties for Europe - Spatial Representation of Soil Database Attributes, Luxembourg, 2013a.

Hiederer, R.: Mapping soil typologies: spatial decision support applied to the European Soil Database., Publications Office, Lux- embourg, available at: http://dx.publications.europa.eu/10.2788/ 87286 (last access: 20 June 2019), 2013b.

Hough, M. N. and Jones, R. J. A.: The United Kingdom Meteorological Office rainfall and evaporation calculation system: MORECS version 2.0-an overview, Hydrol. Earth Syst. Sci., 1, 227-239, https://doi.org/10.5194/hess-1-227-1997, 1997.

Hughes, M., Hornby, D. D., Bennion, H., Kernan, M., Hilton, J., Phillips, G., and Thomas, R.: The Development of a GIS-based Inventory of Standing Waters in Great Britain together with a Risk-based Prioritisation Protocol, Water Air Soil Pollut. Focus, 4, 73-84, https://doi.org/10.1023/B:WAFO.0000028346.27904.83, 2004.

Hutton, C., Wagener, T., Freer, J., Han, D., Duffy, C., and Arheimer, B.: Most computational hydrology is not reproducible, so is it really science?, Water Resour. Res., 52, 7548-7555, https://doi.org/10.1002/2016WR019285, 2016.

Jenkins, G. J., Perry, M., Prior, J., UKCIP09 and UK Climate Impacts Programme: The climate of the United Kingdom and recent trends, Met Office Hadley Centre, Exete, available at: http: //www.ukcip.org.uk/images/stories/08_pdfs/Trends.pdf (last access: 12 December 2019), 2009.

Keller, V. D. J., Tanguy, M., Prosdocimi, I., Terry, J. A., Hitt, O., Cole, S. J., Fry, M., Morris, D. G., and Dixon, H.: CEH-GEAR: $1 \mathrm{~km}$ resolution daily and monthly areal rainfall estimates for the UK for hydrological and other applications, Earth Syst. Sci. Data, 7, 143-155, https://doi.org/10.5194/essd-7-143-2015, 2015.

Kiang, J. E., Gazoorian, C., McMillan, H., Coxon, G., Le Coz, J., Westerberg, I. K., Belleville, A., Sevrez, D., Sikorska, A. E., Petersen-Øverleir, A., Reitan, T., Freer, J., Renard, B., Mansanarez, V., and Mason, R.: A Comparison of Methods for Streamflow Uncertainty Estimation, Water Resour. Res., 54, 7149-7176, https://doi.org/10.1029/2018WR022708, 2018.

Koffler, D., Gauster, T., and Laaha, G.: lfstat: Calculation of Low Flow Statistics for Daily Stream Flow Data version 0.9.8 from RForge, available at: https://rdrr.io/rforge/lfstat/ (last access: 7 October 2019), 2016.

Kollat, J. B., Reed, P. M., and Wagener, T.: When are multiobjective calibration trade-offs in hydrologic models meaningful?, Water Resour. Res., 48, W03520, https://doi.org/10.1029/2011WR011534, 2012.

Kuentz, A., Arheimer, B., Hundecha, Y., and Wagener, T.: Understanding hydrologic variability across Europe through catchment classification, Hydrol. Earth Syst. Sci., 21, 2863-2879, https://doi.org/10.5194/hess-21-2863-2017, 2017.

Ladson, A. R., Brown, R., Neal, B., and Nathan, R.: A Standard Approach to Baseflow Separation Using The Lyne and Hollick Filter, Australas, J. Water Resour., 17, 25-34, https://doi.org/10.7158/13241583.2013.11465417, 2013.

Lane, R. A., Coxon, G., Freer, J. E., Wagener, T., Johnes, P. J., Bloomfield, J. P., Greene, S., Macleod, C. J. A., and Reaney, S. M.: Benchmarking the predictive capability of hydrological models for river flow and flood peak predictions across over 1000 catchments in Great Britain, Hydrol. Earth Syst. Sci., 23, 40114032, https://doi.org/10.5194/hess-23-4011-2019, 2019.

Lee, H., McIntyre, N., Wheater, H., and Young, A.: Selection of conceptual models for regionalisation of the rainfall-runoff relationship, J. Hydrol., 312, 125-147, https://doi.org/10.1016/j.jhydrol.2005.02.016, 2005. 
Lehner, B., Liermann, C. R., Revenga, C., Vörösmarty, C., Fekete, B., Crouzet, P., Döll, P., Endejan, M., Frenken, K., Magome, J., Nilsson, C., Robertson, J. C., Rödel, R., Sindorf, N., and Wisser, D.: High-resolution mapping of the world's reservoirs and dams for sustainable river-flow management, Front. Ecol. Environ., 9, 494-502, https://doi.org/10.1890/100125, 2011.

Lewis, E., Quinn, N., Blenkinsop, S., Fowler, H. J., Freer, J., Tanguy, M., Hitt, O., Coxon, G., Bates, P., and Woods, R.: A rule based quality control method for hourly rainfall data and a $1 \mathrm{~km}$ resolution gridded hourly rainfall dataset for Great Britain: CEH-GEAR1hr, J. Hydrol., 564, 930-943, https://doi.org/10.1016/j.jhydrol.2018.07.034, 2018.

Marsh, T. and Hannaford, J.: UK hydrometric register. A catalogue of river flow gauging stations and observation wells and boreholes in the United Kingdom together with summary hydrometric and spatial statistics, edited by T. Marsh and J. Hannaford, Centre for Ecology \& Hydrology, Wallingford, available at: http://nora.nerc.ac.uk/id/eprint/3093/ (last access: 16 July 2019), 2008.

Marsh, T., Cole, G., and Wilby, R.: Major droughts in England and Wales, 1800-2006, Weather, 62, 87-93, https://doi.org/10.1002/wea.67, 2007.

McDonnell, J. J., Sivapalan, M., Vaché, K., Dunn, S., Grant, G., Haggerty, R., Hinz, C., Hooper, R., Kirchner, J., Roderick, M. L., Selker, J., and Weiler, M.: Moving beyond heterogeneity and process complexity: A new vision for watershed hydrology, Water Resour. Res., 43, W07301, https://doi.org/10.1029/2006WR005467, 2007.

McMillan, H., Montanari, A., Cudennec, C., Savenije, H., Kreibich, H., Krueger, T., Liu, J., Mejia, A., Loon, A. V., Aksoy, H., Baldassarre, G. D., Huang, Y., Mazvimavi, D., Rogger, M., Sivakumar, B., Bibikova, T., Castellarin, A., Chen, Y., Finger, D., Gelfan, A., Hannah, D. M., Hoekstra, A. Y., Li, H., Maskey, S., Mathevet, T., Mijic, A., Acuña, A. P., Polo, M. J., Rosales, V., Smith, P., Viglione, A., Srinivasan, V., Toth, E., van Nooyen, R., and Xia, J.: Panta Rhei 2013-2015: global perspectives on hydrology, society and change, Hydrol. Sci. J., 61, 1174-1191, https://doi.org/10.1080/02626667.2016.1159308, 2016.

Merz, R. and Blöschl, G.: Regionalisation of catchment model parameters, J. Hydrol., 287, 95-123, https://doi.org/10.1016/j.jhydrol.2003.09.028, 2004.

Mizukami, N., Clark, M. P., Newman, A. J., Wood, A. W., Gutmann, E. D., Nijssen, B., Rakovec, O., and Samaniego, L.: Towards seamless large-domain parameter estimation for hydrologic models, Water Resour. Res., 53, 8020-8040, https://doi.org/10.1002/2017WR020401, 2017.

Montanari, A., Young, G., Savenije, H. H. G., Hughes, D., Wagener, T., Ren, L. L., Koutsoyiannis, D., Cudennec, C., Toth, E., Grimaldi, S., Blöschl, G., Sivapalan, M., Beven, K., Gupta, H., Hipsey, M., Schaefli, B., Arheimer, B., Boegh, E., Schymanski, S. J., Baldassarre, G. D., Yu, B., Hubert, P., Huang, Y., Schumann, A., Post, D. A., Srinivasan, V., Harman, C., Thompson, S., Rogger, M., Viglione, A., McMillan, H., Characklis, G., Pang, Z., and Belyaev, V.: "Panta Rhei - Everything Flows": Change in hydrology and society - The IAHS Scientific Decade 2013-2022, Hydrol. Sci. J., 58, 1256-1275, https://doi.org/10.1080/02626667.2013.809088, 2013.

Moore, R. V., Morris, D. G., and Flavin, R. W.: CEH digital river network of Great Britain (1:50,000),
EIDC, available at: https://catalogue.ceh.ac.uk/id/ 7d5e42b6-7729-46c8-99e9-f9e4efddde1d (last access: 2 November 2019), 2000.

Morris, D. G. and Flavin, R. W.: A digital terrain model for hydrology, in Proc 4th International Symposium on Spatial Data Handling, Vol. 1, 250-262, Zürich, 1990.

Muchan, K. and Dixon, H.: Ensuring hydrometric data are fit-forpurpose through a national Service Level Agreement, in: Hydrology in a changing world: environmental and human dimensions, edited by: Daniell, T. M., pp. 323-329, International Association of Hydrological Sciences, Wallingford, UK, available at: http://nora.nerc.ac.uk/id/eprint/502971/ (last access: 22 September 2020), 2014

Nelson, B.: Data sharing: Empty archives, Nature, 461, 160-163, https://doi.org/10.1038/461160a, 2009.

NERC: Flood Studies Report, London, 1975.

Newman, A. J., Clark, M. P., Sampson, K., Wood, A., Hay, L. E., Bock, A., Viger, R. J., Blodgett, D., Brekke, L., Arnold, J. R., Hopson, T., and Duan, Q.: Development of a large-sample watershed-scale hydrometeorological data set for the contiguous USA: data set characteristics and assessment of regional variability in hydrologic model performance, Hydrol. Earth Syst. Sci., 19, 209-223, https://doi.org/10.5194/hess-19-209-2015, 2015.

Parajka, J., Merz, R., and Blöschl, G.: A comparison of regionalisation methods for catchment model parameters, Hydrol. Earth Syst. Sci., 9, 157-171, https://doi.org/10.5194/hess-9-157-2005, 2005.

Pelletier, J. D., Broxton, P. D., Hazenberg, P., Zeng, X., Troch, P. A., Niu, G., Williams, Z., Brunke, M. A., and Gochis, D.: A gridded global data set of soil, intact regolith, and sedimentary deposit thicknesses for regional and global land surface modeling, J. Adv. Model. Earth Syst., 8, 41-65, https://doi.org/10.1002/2015MS000526, 2016a.

Pelletier, J. D., Broxton, P. D., Hazenberg, P., Zeng, X., Troch, P. A., Niu, G., Williams, Z. C., Brunke, M. A., and Gochis, D.: Global 1-km Gridded Thickness of Soil, Regolith, and Sedimentary Deposit Layers, ORNL DAAC, https://doi.org/10.3334/ORNLDAAC/1304, 2016b.

Perrin, C., Michel, C., and Andréassian, V.: Improvement of a parsimonious model for streamflow simulation, J. Hydrol., 279, 275 289, https://doi.org/10.1016/S0022-1694(03)00225-7, 2003.

Pool, S., Viviroli, D., and Seibert, J.: Value of a Limited Number of Discharge Observations for Improving Regionalization: A Large-Sample Study Across the United States, Water Resour. Res., 55, 363-377, https://doi.org/10.1029/2018WR023855, 2019.

Robinson, E. L., Blyth, E., Clark, D. B., Comyn-Platt, E., Finch, J., and Rudd, A. C.: Climate hydrology and ecology research support system potential evapotranspiration dataset for Great Britain (1961-2015) [CHESS-PE], NERC Environ. Inf. Data Cent., https://doi.org/10.5285/8baf805d-39ce-4dac-b224c926ada353b7, 2016.

Robinson, E. L., Blyth, E., Clark, D. B., Comyn-Platt, E., Finch, J., and Rudd, A. C.: Climate hydrology and ecology research support system meteorology dataset for Great Britain (1961-2015) [CHESS-met] v1.2, NERC Environ. Inf. Data Cent., https://doi.org/10.5285/b745e7b1-626c-4ccc-ac2756582e77b900, 2017a. 
Robinson, E. L., Blyth, E. M., Clark, D. B., Finch, J., and Rudd, A. C.: Trends in atmospheric evaporative demand in Great Britain using high-resolution meteorological data, Hydrol. Earth Syst. Sci., 21, 1189-1224, https://doi.org/10.5194/hess-21-1189-2017, $2017 \mathrm{~b}$.

Rowland, C. S., Morton, R. D., Carrasco, L., McShane, G., O'Neil, A. W., and Wood, C. M.: Land Cover Map 2015 $(1 \mathrm{~km}$ percentage target class, GB), NERC Environ. Inf. Data Cent., https://doi.org/10.5285/505d1e0c-ab60-4a60-b44868c5bbae403e, 2017.

Samaniego, L., Kumar, R., and Attinger, S.: Multiscale parameter regionalization of a grid-based hydrologic model at the mesoscale, Water Resour. Res., 46, W05523, https://doi.org/10.1029/2008WR007327, 2010.

Sankarasubramanian, A., Vogel, R. M., and Limbrunner, J. F.: Climate elasticity of streamflow in the United States, Water Resour. Res., 37, 1771-1781, https://doi.org/10.1029/2000WR900330, 2001.

Sawicz, K., Wagener, T., Sivapalan, M., Troch, P. A., and Carrillo, G.: Catchment classification: empirical analysis of hydrologic similarity based on catchment function in the eastern USA, Hydrol. Earth Syst. Sci., 15, 2895-2911, https://doi.org/10.5194/hess-15-2895-2011, 2011.

Singh, R., van Werkhoven, K., and Wagener, T.: Hydrological impacts of climate change in gauged and ungauged watersheds of the Olifants basin: a tradingspace-for-time approach, Hydrol. Sci. J., 59, 29-55, https://doi.org/10.1080/02626667.2013.819431, 2014.

Stahl, K., Hisdal, H., Hannaford, J., Tallaksen, L. M., van Lanen, H. A. J., Sauquet, E., Demuth, S., Fendekova, M., and Jódar, J.: Streamflow trends in Europe: evidence from a dataset of nearnatural catchments, Hydrol. Earth Syst. Sci., 14, 2367-2382, https://doi.org/10.5194/hess-14-2367-2010, 2010.

Stevens, A. J., Clarke, D., and Nicholls, R. J.: Trends in reported flooding in the UK: 1884-2013, Hydrol. Sci. J., 61, 50-63, https://doi.org/10.1080/02626667.2014.950581, 2016.

Tanguy, M., Dixon, H., Prosdocimi, I., Morris, D. G., and Keller, V. D. J.: Gridded estimates of daily and monthly areal rainfall for the United Kingdom (1890-2015) [CEH-GEAR], NERC Environ. Inf. Data Cent., https://doi.org/10.5285/33604ea0-c2384488-813d-0ad9ab7c51ca, 2016.

Tanguy, M., Prudhomme, C., Smith, K., and Hannaford, J.: Historical gridded reconstruction of potential evapotranspiration for the UK, Earth Syst. Sci. Data, 10, 951-968, https://doi.org/10.5194/essd-10-951-2018, 2018.

Thompson, N., Barrie, I. A., and Ayles, M.: The Meteorological Office rainfall and evaporation calculation system: MORECS, Meteorol. Off. Bracknell, 1981.

Tyralis, H., Papacharalampous, G., and Tantanee, S.: How to explain and predict the shape parameter of the generalized extreme value distribution of streamflow extremes using a big dataset, J. Hydrol., 574, 628-645, https://doi.org/10.1016/j.jhydrol.2019.04.070, 2019.
Viglione, A., Borga, M., Balabanis, P., and Blöschl, G.: Barriers to the exchange of hydrometeorological data in Europe: Results from a survey and implications for data policy, J. Hydrol., 394, 63-77, https://doi.org/10.1016/j.jhydrol.2010.03.023, 2010.

Wagener, T., Sivapalan, M., Troch, P. A., McGlynn, B. L., Harman, C. J., Gupta, H. V., Kumar, P., Rao, P. S. C., Basu, N. B., and Wilson, J. S.: The future of hydrology: An evolving science for a changing world, Water Resour. Res., 46, https://doi.org/10.1029/2009WR008906, 2010.

Werkhoven, K., Wagener, T., Reed, P., and Tang, Y.: Characterization of watershed model behavior across a hydroclimatic gradient, Water Resour. Res., 44, W01429, https://doi.org/10.1029/2007WR006271, 2008.

Westerberg, I. K. and McMillan, H. K.: Uncertainty in hydrological signatures, Hydrol. Earth Syst. Sci., 19, 3951-3968, https://doi.org/10.5194/hess-19-3951-2015, 2015.

Westerberg, I. K., Wagener, T., Coxon, G., McMillan, H. K., Castellarin, A., Montanari, A., and Freer, J.: Uncertainty in hydrological signatures for gauged and ungauged catchments, Water Resour. Res., 52, 1847-1865, https://doi.org/10.1002/2015WR017635, 2016.

Woods, R. A.: Analytical model of seasonal climate impacts on snow hydrology: Continuous snowpacks, Adv. Water Resour., 32, 1465-1481, https://doi.org/10.1016/j.advwatres.2009.06.011, 2009.

World Meteorological Organization (Geneva): Manual on low-flow estimation and prediction, WMO, Geneva, 2008.

Wösten, J. H. M., Lilly, A., Nemes, A., and Le Bas, C.: Development and use of a database of hydraulic properties of European soils, Geoderma, 90, 169-185, https://doi.org/10.1016/S00167061(98)00132-3, 1999.

Wösten, J. H. M., Pachepsky, Y. A., and Rawls, W. J.: Pedotransfer functions: bridging the gap between available basic soil data and missing soil hydraulic characteristics, J. Hydrol., 251, 123-150, https://doi.org/10.1016/S0022-1694(01)00464-4, 2001.

Wösten, J. J. H.: The HYPRES database of hydraulic properties of European soils, in: Subsoil compaction; distribution, processes and consequences, edited by: R. Horn, J. J. H., van den Akker, and Arvidsson, J., 135-143, 2000.

Yadav, M., Wagener, T., and Gupta, H.: Regionalization of constraints on expected watershed response behavior for improved predictions in ungauged basins, Adv. Water Resour., 30, 17561774, https://doi.org/10.1016/j.advwatres.2007.01.005, 2007.

Zacharias, S., Bogena, H., Samaniego, L., Mauder, M., Fuß, R., Pütz, T., Frenzel, M., Schwank, M., Baessler, C., ButterbachBahl, K., Bens, O., Borg, E., Brauer, A., Dietrich, P., Hajnsek, I., Helle, G., Kiese, R., Kunstmann, H., Klotz, S., Munch, J. C., Papen, H., Priesack, E., Schmid, H. P., Steinbrecher, R., Rosenbaum, U., Teutsch, G., and Vereecken, H.: A Network of Terrestrial Environmental Observatories in Germany, Vadose Zone J., 10, 955, https://doi.org/10.2136/vzj2010.0139, 2011. 